Portland State University

PDXScholar

\title{
Assessing Soil Lead Contamination at Multiple Scales in Oakland, California: Implications for Urban Agriculture and Environmental Justice
}

Nathan McClintock

Portland State University, n.mcclintock@pdx.edu

Follow this and additional works at: https://pdxscholar.library.pdx.edu/usp_fac

Part of the Social Policy Commons, Urban Studies Commons, and the Urban Studies and Planning Commons

Let us know how access to this document benefits you.

\section{Citation Details}

McClintock, Nathan, "Assessing Soil Lead Contamination at Multiple Scales in Oakland, California: Implications for Urban Agriculture and Environmental Justice" (2012). Urban Studies and Planning Faculty Publications and Presentations. 94.

https://pdxscholar.library.pdx.edu/usp_fac/94

This Post-Print is brought to you for free and open access. It has been accepted for inclusion in Urban Studies and Planning Faculty Publications and Presentations by an authorized administrator of PDXScholar. Please contact us if we can make this document more accessible: pdxscholar@pdx.edu. 
Applied Geography

Original research article submission

Assessing soil lead contamination at multiple scales in Oakland, California: Implications for urban agriculture and environmental justice

Nathan McClintock *,1

Department of Geography, 507 McCone Hall, \#4740, University of California, Berkeley, CA 94720, USA

\section{Abstract:}

As urban agriculture grows in popularity throughout North America, vacant lots, underutilized parks, and other open spaces are becoming prime targets for food production. In many postindustrial landscapes and in neighborhoods with a high density of old housing stock, the risk of lead $(\mathrm{Pb})$ contamination at such sites is raising concerns. This paper evaluates the extent to which soil $\mathrm{Pb}$ contamination may be an obstacle to the expansion of urban agriculture in Oakland, California. Using a combination of soil sampling at 112 sites, GIS, "hot spot" analysis, and reconstructed land use histories, the research reveals that soil $\mathrm{Pb}$ concentrations are generally lower than federal screening levels of $400 \mathrm{ppm}$, but significantly higher in West Oakland, the city's oldest area and home to a predominantly low-income and African American population. Lead levels are significantly lower in the affluent, predominantly white Oakland hills. Spatial analysis at city- and neighborhood-scales reveals clusters of $\mathrm{Pb}$ contamination related to land use history. Site-scale analyses at 12 sites reveals a high level of variability (in some cases related to land use history) that must be taken into consideration when planning for urban agriculture.

Keywords:

environmental justice; land use; lead contamination; site assessment; vacant lots; urban gardens

* Corresponding author. Tel: +1 503 725 4064; fax: +1 5037258770

E-mail address: n.mcclintock@pdx.edu

${ }^{1}$ Present address: Toulan School of Urban Studies \& Planning, Portland State University, P.O. Box 751, Portland, OR 97207, USA 


\section{Assessing soil lead contamination at multiple scales in Oakland, California: Implications for urban agriculture and environmental justice}

\section{Abstract:}

As urban agriculture grows in popularity throughout North America, vacant lots, underutilized parks, and other open spaces are becoming prime targets for food production. In many postindustrial landscapes and in neighborhoods with a high density of old housing stock, the risk of

lead $(\mathrm{Pb})$ contamination at such sites is raising concerns. This paper evaluates the extent to which soil $\mathrm{Pb}$ contamination may be an obstacle to the expansion of urban agriculture in Oakland, California. Using a combination of soil sampling at 112 sites, GIS, and "hot spot" analysis, and reconstructed land use histories, the research reveals that soil $\mathrm{Pb}$ concentrations are generally lower than federal screening levels of $400 \mathrm{ppm}$, but significantly higher in West Oakland, the city's oldest area and home to a predominantly low-income and African American population. Lead levels are significantly lower in the affluent, predominantly white Oakland hills. Spatial analysis at city- and neighborhood-scales reveals clusters of $\mathrm{Pb}$ contamination related to land use history. Site-scale analyses at 12 sites reveals a high level of variability (in some cases related to land use history) that must be taken into consideration when planning for urban agriculture.

\section{Keywords:}

environmental justice; land use; lead contamination; site assessment; vacant lots; urban gardens 


\section{Introduction ${ }^{1}$}

As urban agriculture grows in popularity, vacant parcels in post-industrial cities have become a prime target for cultivation. Many efforts to transform vacant land into verdant and productive agricultural spaces are spearheaded by individuals and organizations eager to provide healthy and nutritious fresh produce to residents of so-called "food deserts", low-income areas where fresh produce and healthy food options are limited or non-existent due low purchasing power and the market logic of supermarket location (Gottlieb and Joshi 2010; Alkon and Agyeman 2011). However, as food production begins to ramp up on such land, public concern is growing over potential environmental hazards. Many vacant lots contain contaminants that may be a material legacy of a site's industrial past, or simply a function of its proximity to a freeway or some other source of airborne pollution (Goldenberg 2009; Murphy 2009; Runk 2011;

Seltenrich 2011). In a cruel twist of irony, much of this vacant land is located within or nearby the very food deserts that food justice-oriented urban agriculturalists intend to serve. Indeed, the same socio-spatial processes responsible for deindustrialization and economic disinvestment can explain the decline in availability of healthy food (Eisenhauer 2001; McClintock 2011a).

Many urban soils exhibit high concentrations of both synthetic organic contaminants, such as polychlorinated biphenyls (PCBs) and other dioxins, polycyclic aromatic hydrocarbons, and volatile organic compounds (Krauss and Wilcke 2003; Aichner et al 2007) and heavy metals such as arsenic (As), cadmium $(\mathrm{Cd})$, chromium $(\mathrm{Cr})$, lead $(\mathrm{Pb})$, mercury $(\mathrm{Hg})$, nickel $(\mathrm{Ni})$, and

\footnotetext{
${ }^{1}$ Abbreviations used in this article: $\mathrm{CEC}=$ cation exchange capacity; $\mathrm{CHHSL}=$ California Human Health Screening Level; EBMUD = East Bay Municipal Utilities District; EPA = United States Environmental Protection Agency; NAIP = National Agriculture Imagery Program; OM = organic matter; OPR = Oakland Parks and Recreation Department
} 
zinc (Zn) (Sanchez-Camazano et al 1994; Alloway 2004). Their presence, which originates from both point and non-point sources, has elicited concerns among researchers that produce grown in urban gardens may place the health of consumers at risk (Scheyer 2004; Nabulo et al 2006).

Lead tends to headline discussions over the potential risks of urban agriculture, both because it is ubiquitous in urban areas and because of the health risks it poses. Ingestion of soil and dust are primary pathways of exposure to $\mathrm{Pb}$ and a large body of research has shown direct correlations between soil $\mathrm{Pb}$ and blood $\mathrm{Pb}$ levels. Children are particularly susceptible to $\mathrm{Pb}$ poisoning; while adults generally absorb less than $5 \%$ of ingested $\mathrm{Pb}$, children absorb up to $50 \%$ (Mielke et al 1983, 2007; Mielke and Reagan 1998; Laidlaw and Fillippelli 2008).

Lead in urban soils comes from several sources. In industrial areas, $\mathrm{Pb}$ is generally attributed to atmospheric deposition downwind from smelting (Rawlins et al 2006; Douay et al 2007; Schulin et al 2007). Along highways, Pb contamination is attributed to exhaust emissions (Gratani et al 1992; Teichman et al 1993). In residential areas, most $\mathrm{Pb}$ contamination is attributed to paint used for housing (Sutton et al 1995; Clark et al 2006; Wu et al 2010). Over 6 million $\mathrm{Mg}$ of $\mathrm{Pb}$ was used in paint in the US between the 1880s and the late 1970s, peaking at 1.2 million $\mathrm{Mg}$ used in the 1920s. Even though $\mathrm{Pb}$ concentrations in paint declined steeply by mid-century, high levels of $\mathrm{Pb}$ remain on the interior and exterior walls houses to this day (Mielke and Reagan 1998; Mielke et al 2008). A US Department of Housing and Urban Development study estimated that in the US, lead paint covers 1.046 million $\mathrm{mi}^{2}$ (2.079 million $\mathrm{km}^{2}$ ) - roughly a third of the total area of the US — of exterior surfaces of housing stock in the United States, or an average of $996 \mathrm{ft}^{2}\left(92.53 \mathrm{~m}^{2}\right)$ of lead-based paint per housing unit (Jacobs et al 2002). Much of the exterior paint $\mathrm{Pb}$ has ended up in the soil over the past century (Mielke et al 1984; Sutton et al 1995); one study reports that 52\% of houses built in the US before 1978 
have yard soil Pb levels $>400 \mathrm{mg} \mathrm{kg}^{-1}$, the US Environmental Protection Agency (EPA) screening level for soil $\mathrm{Pb}$ contamination (Jacobs et al 2002).

Systematic studies of soil contamination on vacant land are vital in order to protect the public from potential risks associated with the expansion of the very urban agriculture programs established to increase access to healthy food. Such an approach represents the application of the "precautionary principle" (Morello-Frosch et al 2002), in that possible contamination risk should be assessed before UA projects are started in order to ensure that urban soil is safe for food production. This paper details the assessment of existing and potential urban garden sites in Oakland, California, identifying potential contamination at selected sites, while contributing to a broader understanding of how particular land uses impact soil $\mathrm{Pb}$ levels. More specifically, the research attempts to: 1) quantify average soil $\mathrm{Pb}$ concentrations across Oakland; 2) characterize variation in soil $\mathrm{Pb}$ across land uses and geographic regions at the city-scale; and 3) assess variation in soil $\mathrm{Pb}$ levels at the city-, neighborhood-, and site-scales. Finally, it bridges applied geographic environmental justice scholarship on exposure to contaminants and other hazards contaminants and other hazards in urban areas (Maantay and Maroko 2009; Maroko 2012) to a rapidly growing body of scholarship devoted to mapping food environments (Gatrell, Reid, and Ross 2011), both in terms of access (Eckert and Shetty 2011; Hallett and McDermott 2011) as well as the impact of existing and potential sites of production (Corrigan 2011; Metcalf and Widener 2011; Kremer and DeLiberty 2011).

\section{Methods}

\subsection{Study area description}


This study was conducted in Oakland, California (UTM 10N 37.804444, -122.270833). Three primary topographic zones define the city's physical geography: flatlands, foothills, and hills. The flatlands are low-lying areas adjacent to the San Francisco Bay to the city's west and Alameda Estuary and San Leandro Bay to the south. A large percentage of this land is comprised of fill (e.g., dredged sediment, construction debris, quarried rocks), particularly around the Port of Oakland and the Oakland airport (Welch 1981). The foothills are formed on a gentle fan of alluvium spreading downwards from the Oakland hills, a series of undulating, parallel ridges running along the city's eastern portion along a northwest-southeast axis. Part of the state's Coast Range, the Oakland hills have been thrust upwards along the Hayward and Moraga faults over the past million years (Sloan 2006). Soils are a mix of urban land (highly mixed, heterogeneous fill) and urban land complexes. Endogenous soil series in the flatlands are derived from sedimentary, alluvial parent material, while the hills are dominated by a number of excessively drained loams weathered from uplifted conglomerate and ultrabasic metamorphic rock (Welch 1981). The region's climate is Mediterranean with wet winters and dry summers with morning fog. September is the hottest month with an average high temperature of $27^{\circ} \mathrm{C}$ $\left(80.6^{\circ} \mathrm{F}\right)$, while January is the coldest month with an average high of $14.5^{\circ} \mathrm{C}\left(58.1^{\circ} \mathrm{F}\right)$. Average annual precipitation is $582.7 \mathrm{~mm}$ (22.9"), with the majority (89\%) of the total rainfall occurring between November and April (NOAA 2004). Native vegetation consists of a mosaic of plant communities, including oak woodland, coastal shrub, and coastal terrace prairie, with large coniferous (redwood) stands in the drainages (Beidleman and Kozloff 2003).

One of three major cities in the San Francisco Bay Area, Oakland has a population of 391,000. The city's bifurcated physical geography of flatlands and hills, which is roughly delimited by two freeways, also marks socioeconomic differences. Census data reveal a 
disproportionate concentration of poverty in the flatlands of North, West, and East Oakland, affecting a population that is majority African American, Southeast Asian, and Latino. Most of Oakland's white population lives in the more affluent foothills and hills neighborhoods (U.S. Census Bureau 2010). The highly spatialized nature of the socioeconomic landscape is due in large part to a history of insurance redlining and racial covenants in the first half of the $20^{\text {th }}$ century and to freeway construction and deindustrialization during the 1960s and 1970s, which demarcated not only areas where particular ethnic groups were allowed to live, but also where investment capital flowed (Walker 2001; Self 2003; McClintock 2011a).

This bifurcation of the socioeconomic landscape into hills and flatlands has defined access to healthy and affordable food in Oakland (Beyers et al 2008; OFPC 2010). Areas with limited access to healthy food—-so-called "food deserts"—-are located in the flatlands and are closely tied to the history of disinvestment (HOPE Collaborative 2009; Treuhaft et al 2009; McClintock 2011a). Over the last decade, several food justice organizations have attempted to address inequitable food access through a variety of programs and policy initiatives. Urban agriculture has figured largely into these efforts and has begun to figure prominently in food systems, public health, and land use planning discussions in Oakland (McClintock et al, 2012).

\subsection{Context of the project}

This project emerged in conjunction with research conducted by the author in collaboration with the HOPE Collaborative, a W.K. Kellogg Foundation-funded umbrella organization convening public agencies, non-profit organizations, and community members and funded by the program to address inequities in Oakland's food system and built environment (Herrera et al 2009; HOPE Collaborative 2009). Working with a community advisory committee 
comprised of HOPE Collaborative members, the author and a research assistant conducted an inventory of vacant land with agricultural potential (McClintock and Cooper 2009). During the inventory, advisory committee members, many of whom represented urban agriculture and food justice organizations, expressed concern that vacant land in the flatlands might be contaminated and that food production on these lots might expose consumers to health risks. Despite their well-intentioned efforts to expand food production on vacant land, no systematic assessment had yet been conducted due to the labor required for sampling and the costs associated with soil

analysis. To address this concern, the author applied for and received pilot funding from the University of California Division of Agriculture and Natural Resources Analytical Lab to assess a selection of sites identified by the inventory. The project was scaled up considerably in 2010 following receipt of additional funding from the National Science Foundation. The intent of this second phase was to identify larger-scale spatial trends in soil $\mathrm{Pb}$ contamination, while getting baseline soil $\mathrm{Pb}$ data for a much larger pool of existing and potential urban garden sites.

\subsection{Sampling site selection}

[FIGURE 1 about here]

In 2009, the community advisory committee selected 20 of 495 potential urban agriculture sites identified in the vacant land inventory. The group based their selection on size, proximity to underserved populations, accessibility to public transport, and equal distribution across the Oakland flatlands. In 2010, an additional 140 sites were selected from the inventory in order to map the spatial distribution of $\mathrm{Pb}$ levels at the city-scale. Efforts were made to select sites from all regions of the city. Twenty sites were randomly selected from each of Oakland's seven City Council Districts using ArcGIS. Following site visits, however, many of these sites 
were excluded due to inaccessibility (fences, vegetation, or steep slopes). Several new sites were later selected from the inventory to fill in geographic gaps. For the most part, sites were evenly distributed across five geographic zones in the flatlands (North, West, Central, and East Oakland) and the Oakland hills (see Figure 1). A Moran's I test of spatial autocorrelation verified that sites were randomly spaced across the city rather than clustered. Upon sampling, each site was classified within a typology of four land use types: garden; park; vacant; or open space (see Table 2). Each land use type served as a proxy for different edaphic types related to the level of anthropogenic disturbance and vegetation typically encountered in a site under such land use. Figure 2 provides a visual example of each of these land use types.

[Table 1 about here]

[Figure 2 about here]

\subsection{Plant sampling}

To qualitatively characterize the vegetation the four land use types listed in Table 1, representative samples were collected from two vacant sites and two open space sites and identified using a botanical key (Beidleman and Kozloff 2003). Turf grass species were identified using the online Statewide Integrated Pest Management Program website (UCDANR 2012).

\subsection{Soil sampling and analysis}

\subsubsection{Site-scale sampling}

In July 2009 , eleven of the twenty sites identified by the community advisory committee were selected for a finer-grain analysis in order to assess the extent to which Pb levels vary at the 
site-scale. An additional site in West Oakland ( $9^{\text {th }}$ Street) was included in May 2010 on the request of a community development organization interested in developing an urban garden on the site. At the six smallest sites, we overlaid a $25^{\prime} \times 25^{\prime}(7.52 \mathrm{~m} \times 7.52 \mathrm{~m})$ sampling grid in order to detect the spatial distribution of $\mathrm{Pb}$ across the site. At three of the larger sites (King's Estates, Oakport, and Harbor Bay) the grid squares were $50^{\prime} \times 50^{\prime}(15.24 \mathrm{~m} \times 15.24 \mathrm{~m})$. At one of the largest sites (Doolittle), grid squares were 100' $\times 100^{\prime}(30.48 \mathrm{~m} \times 30.48 \mathrm{~m})$, as the site was topographically and edaphically homogenous. At sites where distinctly different soils were visible, each soil was assessed separately (and treated as a separate site); at one site (Oakport), three distinct soils were clearly evident; another (Harbor Bay), two soils were present.

Each grid square was evenly delineated into 9 sub-sections. After surface litter or vegetation was removed, a representative sample was collected from each at a depth of 5 to 10 cm (depending on penetrability) using a stainless-steel core auger. Geospatial coordinates at each sample point were recorded using a Trimble Pathfinder GPS unit (Trimble Navigation, Ltd, Sunnyvale, CA). The nine cores from each grid square were mixed together into a single composite sample (henceforth "grid-sample") representing an average of the grid square. A $10 \mathrm{~g}$ sub-sample was also taken from each grid-sample and composited to form a "site-sample" representing mean values for the entire site.

\subsubsection{City-scale sampling}

For the city-scale sites (10 collected in 2009, 92 collected in 2010), 12 soil cores were collected from a depth of 5 to $10 \mathrm{~cm}$ at points evenly distributed within each site. Because the potentially arable area of each site varied in size, samples were collected in a radius ranging from $25^{\prime}$ to $100^{\prime}$. GPS coordinates were logged for each soil core removed. In addition to these 102 
samples, site-sample data (described in 2.5.1) from each of the 11 site-scale assessments were included in the city-scale dataset, resulting in a total of 113 data points.

\subsubsection{Soil analysis}

All soil samples were oven dried at $70^{\circ} \mathrm{C}$, ground and sieved using a Standard Model No. 3 Wiley Mill (Arthur H. Thomas Co., Philadelphia, PA) with $2 \mathrm{~mm}$ mesh. Total Pb for all samples was determined at the University of California Davis Analytical Lab (Davis, CA) using a nitric acid/hydrogen peroxide closed vessel microwave digestion (Sah and Miller 1992) and Inductively Coupled Plasma Atomic Emission Spectrometry (ICP-AES). All 2009 site-samples were also analyzed at the UC Davis Lab for bulk density, cation exchange capacity (CEC), OM, total $\mathrm{N} \& \mathrm{C}$, exchangeable macro- and micronutrients, and certain metals.

\subsubsection{Neighborhood-scale data}

To assess $\mathrm{Pb}$ distribution at the neighborhood-scale, and to assess if $\mathrm{Pb}$ concentration clusters were visible at a more fine-grained level of analysis, we compared our data to sample data collected by the City Slicker Farms Backyard Garden Program. The organization installs raised garden beds for residents throughout West Oakland and routinely collects soil samples prior to installation. Each data point consists of four composited samples collected with a stainless-steel garden trowel from a depth of $0-10 \mathrm{~cm}$. Two composite samples are generally collected for each site, but additional samples are often collected from larger sites. Samples are sent to the U Mass Soil Testing Laboratory (Amherst, MA) and tested for a range of soil fertility indicators and heavy metals using the modified Morgan method (Wolf and Beegle 1995). 


\subsubsection{Geospatial and statistical analyses}

Points and polygons recorded by the GPS unit were imported into ArcGIS 10 (Esri, Redlands, CA). For site-scale data, we calculated the mean center (a spatial average of XY coordinates) of the nine cores collected in each grid square and joined the new coordinate to the corresponding grid sample data (a composite of the nine cores). The same process was used to calculate the mean center of the 12 cores collected for each of the city-scale data points.

Site-scale data were overlaid onto National Agriculture Imagery Program (NAIP) orthophotos (NRCS 2012). ArcGIS 10 was used for all mapping (Datum/Projection: WGS 1984 UTM Zone $10 \mathrm{~N}$ ) and for calculation of spatial statistics. Data sets were tested for spatial autocorrelation (the degree to which features tend to be geographically clustered or dispersed) using Moran's I test. The test calculates the likelihood that clustering within a dataset appears due to random chance. An index value of 1 equals perfect spatial correlation or clustering, 0 equals a random spatial pattern, and -1 equals perfect dispersion (SAS Institute 2010).

While the Moran's I test is a global test of spatial autocorrelation, where the variance of an individual point is measured against the entire dataset, a local point pattern spatial autocorrelation test can identify individual clusters or "hot spots" within a dataset. The Getis-Ord $\mathrm{G}_{\mathrm{i}}{ }^{*}$ test statistic is calculated by comparing the sum of a point and its nearest neighbors to the sum of all points in a given study area. The statistic, a z-value, indicates where high or low values (i.e., values with high standard deviations from the overall mean) cluster spatially (Getis and Ord 1992). Such an approach has been widely used in applied geographic research to identify clustering of species populations (Ma, Zuckerberg, Porter, and Zhang 2012), diseases (Wang, Guo, and McLafferty 2012), crime incidence (Ceccato and Dolmen 2011), availability of medical care (Zhang, Wong, So, and Lin 2012), and food retailers (Leslie, Frankenfeld, and 
Makara 2012).

Descriptive statistics, means comparisons, and analyses of variance were completed using JMP 9 software (SAS Institute, Cary, NC). One site with a total Pb level of 2,262 $\mathrm{mg} \mathrm{kg}^{-1} \mathrm{was}$ removed as an outlier from analysis, as it was several standard deviations higher than the highest quantile. Reported mean values are followed by the standard error $( \pm$ S.E. $)$. Reported mean values are followed by the standard error ( \pm S.E. $)$. To determine if the data was normally or lognormally distributed, $\mathrm{Pb}$ values (both original and log-transformed) were plotted against quantiles, and fit with a regression line. Additionally, a Shapiro-Wilk W test of the original data revealed that the data was not normally distributed and a Kolmogorov's D test verified that the transformed data was actually lognormal. Four tests of equal variance (O’Brien, BrownForsythe, Levene, and Bartlett tests) revealed that variance between groups for geographic zones, land use types, and zoning types was unequal. As a result, standard statistical comparisons of means and analysis of variance (which assume normal distribution of data) could not be conducted. Since the total $\mathrm{Pb}$ data was also highly skewed and lognormally distributed, comparison of medians and Steel-Dwass multiple comparisons tests for groups of unequal size (a nonparametric version of the Tukey's q-test) were used (SAS Institute 2010).

\subsection{Site-scale land use history}

To investigate land use histories for the site-scale analyses, a number of maps and aerial photographs were consulted. First, Sanborn Fire Insurance maps from 1899, 1903, 1925, and 1952 for each site were downloaded from the ProQuest Digital Sanborn Maps Library (ProQuest 2012). City of Oakland street maps published by the Alameda County Chamber of Commerce in $1902,1909,1918,1923$, and 1937, as well as aerial ortho-photographs (1:300 scale) taken in 
1981 and 1994 for the City of Oakland's Office and Planning and Building were consulted at the University of California Berkeley Earth Sciences Library Map Collection. Finally, NAIP orthophotos from 2005 and 2009 were also consulted.

\section{Results and Discussion}

\subsection{City-scale}

Mean total $\mathrm{Pb}$ concentration was $108.7 \pm 13.7 \mathrm{mg} \mathrm{kg}^{-1}$, and ranged from 3 to $979 \mathrm{mg} \mathrm{kg}^{-1}$. Median $\mathrm{Pb}$ concentration was $63.5 \mathrm{mg} \mathrm{kg}^{-1}$ (see Table 2). The distribution of the data was lognormal and highly skewed (skewness $=3.957$, kurtosis $=18.717$ ), with most sites having $\mathrm{Pb}$ levels under $100 \mathrm{mg} \mathrm{kg}^{-1}$ (see Table 2). The lognormal distribution of $\mathrm{Pb}$ is consistent with previous research on $\mathrm{Pb}$ and other contaminants (Wang and Qin 2007; Liu et al 2010). This trend of lognormality is due to either additive or multiplicative processes; in short, a site that is contaminated tends to become even more contaminated (Blackwood 1992; Limpert et al 2001). The Moran's I test of total $\mathrm{Pb}$ levels revealed no spatial autocorrelation at the city-scale (index $=$ $0.043, \mathrm{p}=0.648)$. The Getis-Ord $\mathrm{G}_{\mathrm{i}}^{*}$ "hot spot" analysis of the city-scale data, however, revealed significant clustering of elevated $\mathrm{Pb}$ concentrations in the southern half of West Oakland, and around San Leandro Bay near the Oakland airport.

[Table 2 around here]

Overall, total soil $\mathrm{Pb}$ levels were much lower than expected. Citywide mean concentrations were far below the EPA's contamination screening levels of $400 \mathrm{mg} \mathrm{kg}^{-1}$ but above the recommended California Human Health Screening Level (CHHSL) of $80 \mathrm{mg} \mathrm{kg}^{-1}$. Total $\mathrm{Pb}$ levels exceeded background levels. Metamorphic ultramafic (or ultrabasic) rock from the mantle, such as Coast Range Oliophites found in the Green Valley complex, are common in 
the Bay Area. These rocks are enriched in metals relative to the average levels in the continental crust (Hornberger et al 1999). In one study, background $\mathrm{Pb}$ levels sampled from Oakland soils derived from Great Valley complex, were $21.5 \mathrm{mg} \mathrm{kg}^{-1}$, as much as twice $\mathrm{Pb}$ concentrations levels found in soils formed from other geologic units (City of Oakland n.d.). Nevertheless, mean soil $\mathrm{Pb}$ in our study was approximately five to seven times higher than background levels previously reported for the Oakland hills (City of Oakland n.d.), California (Goldhaber et al 2009), and the Western United States (Shacklette and Boerngen 1984). We can therefore assume that elevated levels are due to deposition from anthropogenic sources. Mean $\mathrm{Pb}$ levels in Oakland were similar to those found in other urban gardens and urban areas worldwide (Mielke et al 1983; Finster et al 2004; Brown et al 2008; Morillo et al 2008; Shi et al 2008; Witzling et al 2011).

[Figure 3 about here]

Significant differences in total $\mathrm{Pb}$ concentrations were identified between geographic zones and land use types. Figure 3 shows quartile box-and-whisker plots for comparison of medians across (a) geographic zones, (b) land use types, and (c) zoning classification, as well as the geographic distribution of points belonging to these analytical groups. Median $\mathrm{Pb}$ levels in West Oakland were higher than in other parts of the city. Levels were likely higher than in the other geographic zones due to the age of the built environment. West Oakland is the oldest part of the city and the historical nexus of industry, warehousing, and transportation (Scott 1959; Bagwell 1982; Walker 2001).

Furthermore, lead levels here can be attributed to a number of anthropogenic sources. First, smelting and other polluting industries were common in this part of Oakland (Walker 2001, 2007). Second, West Oakland is ringed by freeways. Vehicle exhaust, particularly from the Port 
of Oakland, has been correlated with air pollution in West Oakland (Costa et al 2002; Fisher et al 2006; Palaniappan et al 2006); $\mathrm{Pb}$ contamination originating from vehicle exhaust would have followed these same patterns of deposition. Furthermore, 37\% of the housing stock in West Oakland was built before 1940 (U.S. Census Bureau 2010); indeed, most of the houses in this area date from the 1870s to 1910s (Groth 2004). As in other studies relating soil Pb to housing (Sutton et al 1995; Wu et al 2010), multiple regression analysis of our data reveal that the density of pre-1940s housing stock has a significant effect on total Pb levels (McClintock 2011b).

Mean total soil $\mathrm{Pb}$ concentrations in the Oakland hills were significantly lower than in West Oakland $(\mathrm{p}=0.0032)$, North Oakland $(\mathrm{p}=0.0039)$, Central Oakland $(\mathrm{p}<0.0001)$, and East Oakland $(\mathrm{p}=0.0038)$. Low $\mathrm{Pb}$ levels in the Oakland hills can be attributed to several factors. First, while the area is primarily residential, the housing stock is much younger. Second, most of the samples collected in the hills were collected in open space. A comparison between land use types reveals that $\mathrm{Pb}$ levels in open space were significantly lower than in parks $(\mathrm{p}=0.0124)$, vacant lots $(\mathrm{p}=0.0043)$, and gardens $(\mathrm{p}=0.0310)$. Most of these areas, which are managed by the Oakland Parks and Recreation Department (OPR) or the East Bay Regional Parks District, have never been developed. Not only was construction hindered by steep slopes and residential zoning, but also by the concerted efforts of Bay Area environmentalists during the 1970s to preserve open space (Walker 2007). Such concentration gradients, from low Pb levels in rural or peri-urban areas to high $\mathrm{Pb}$ levels in the urban core, are consistent with other research. In samples taken along three transects across Lubbock, for example, Brown et al. (2008) found that $\mathrm{Pb}$ levels were exponentially lower at the outer edge of the city $\left(2.8 \mathrm{mg} \mathrm{kg}^{-1}\right)$ than in the urban core where they peaked at $174 \mathrm{mg} \mathrm{kg}^{-1}$. Mielke et al. found similar patterns in Baltimore (1983) and New Orleans (2007). 
Much of the open space (as a land use classification) in East Oakland, however, actually lies in areas zoned for industry along the Alameda Estuary and San Leandro Bay (see Figures 3b and 3c). Total $\mathrm{Pb}$ levels in East Oakland's open space (223 $\left.\mathrm{mg} \mathrm{kg}^{-1}\right)$ were almost ten times higher than in the hills. Median $\mathrm{Pb}$ levels in industrial zones were higher than residential and open space zones, and mean total $\mathrm{Pb}$ levels slightly higher than in areas zoned as urban open space $(\mathrm{p}=0.0879)$.

Median $\mathrm{Pb}$ levels in park soils were slightly higher than under open space land use, but lower than soils in gardens and vacant lots. As a land use classification, parks were defined by a predominance of turf grass. In general, turf grass grown elsewhere is laid down during development of a park. Lead concentrations are therefore only a measure of the total $\mathrm{Pb}$ deposited since the site's development. While the age of parks varies considerably, some are obviously recent (as evidenced by new construction and landscaping), which would result in lower $\mathrm{Pb}$ levels than in adjacent soils. Lead levels in gardens are likely elevated due to the fact that most are located in residential zones, where $\mathrm{Pb}$ contamination from old housing stock is highest. Moreover, all sampled gardens are located in some of the oldest parts of the city: North, West, and Central Oakland.

\subsection{Neighborhood-scale}

Overall, estimated total $\mathrm{Pb}$ concentrations at 116 houses in West Oakland were higher than citywide averages, but similar to the West Oakland levels identified in the city-scale analysis (see Table 3 and Figure 4). Estimated total $\mathrm{Pb}$ ranged from 0 to 3,329 $\mathrm{mg} \mathrm{kg}^{-1}$, with a mean of $370 \mathrm{mg} \mathrm{kg}^{-1}$ and a median of $273 \mathrm{mg} \mathrm{kg}^{-1}$. Like the city-scale data, distribution was lognormal (skewness $=4.16$, kurtosis $=24.74)$. 
[Table 3 about here]

[Figure 4 about here]

A Moran's I test of spatial autocorrelation for the West Oakland data revealed no significant clustering of total $\mathrm{Pb}$ concentrations (index score $=0.062, \mathrm{p}=0.706$ ). A Getis-Ord $\mathrm{G}_{\mathrm{i}}{ }^{*}$ test on the neighborhood-scale data, however, revealed some significant clustering of elevated $\mathrm{Pb}$ levels in the southwest corner of West Oakland, mirroring "hot spots" that were also identified in a similar analysis of the city-scale data (see Figure 5). The clusters identified in both the cityscale and West Oakland datasets is adjacent to a brownfield, the former site of the Phoenix Iron Works, a foundry that operated from 1901 until the early 1990s when the relocation of the Cypress Freeway forced it to shut its doors (Letzing 2004). Lead is emitted as a byproduct of iron smelting and elevated soil $\mathrm{Pb}$ levels are common in areas surrounding iron smelters (Schulin et al 2007; Zhang et al 2011).

[Figure 5 about here]

The neighborhood-scale data also reveal a "cold spot", where low values are clustered together along Union and $10^{\text {th }}$ Streets. Residential yards where the samples were collected in these areas belong to units in the Acorn Apartments, public housing that was built in 1996 after the original 1960s Acorn housing project was razed. With the new construction, original soil was likely removed and new soil and turfgrass brought in during landscaping.

\subsection{Site-scale}

[Figure 6 about here]

[Table 4 about here] 
Analysis of eleven sites reveals that $\mathrm{Pb}$ concentrations vary significantly at the site-scale. Variability at each site was generally high (see Table 4), particularly in West Oakland. As expected, $\mathrm{Pb}$ levels at the two West Oakland residential sites (Filbert and $9^{\text {th }}$ Street, Figures $6 \mathrm{a}$ and $6 \mathrm{~b}$, respectively) were much higher than EPA screening levels. These high levels are consistent with their geographic location and the age of the neighborhood, as explained in the city-scale results above. According to Sanborn Fire Insurance maps, dwellings stood on both sites as late as 1952. While clustering of elevated $\mathrm{Pb}$ levels at the western end of the $9^{\text {th }}$ Street site do not lie on the footprint of the house, the area was littered with garbage and appears to have been used as a dumping ground in the past.

$\mathrm{Soil} \mathrm{Pb}$ levels in other parts of the city were generally lower, with the exception of two sites in East Oakland, Oakport and Harbor Bay Parkway (Figures 6e and 6i, respectively), both of which are located in industrial areas built on artificial fill along next to the San Leandro Bay. Maps and aerial photography indicate a century of disturbance at both sites. The Oakport site is located on East Bay Municipal Utilities District (EBMUD) land, and is managed by the East Bay Regional Parks District as part of the Martin Luther King, Jr. Regional Shoreline. A 1918 map shows an island in the tidal flats owned by the Barbour Chemical Co. where the Oakport site is currently located (see Figure 7a), with ownership changing hands several times over the first half of the century, before coming under EBMUD ownership. The shoreline was transformed dramatically in the late 1960s. In June 1967 the San Francisco Bay Conservation and Development Commission approved an application by the EBMUD and the Pacific Gas and Electric Corp. "for the dredging of a new and straightened channel for East Creek Slough and the filling of the old meandering channel" (Oakland Tribune 1967). Much of the tidal wetlands were covered with fill in the 1980s, but by the early 1990s had been developed into an open space 
area. While the adjacent shoreline has remained the same for more than forty years, fill is occasionally added to the site. The soil at the northern end of the site (Soil 3) approached EPA screening levels, while those at the southern and central end (soils 1 and 2) were much closer to background levels (see Figure 6f). Soils 1 and 2, which were sandier than soil 3 (89, 82, and 67\% sand, respectively), appear to have been deposited recently; During sampling, a noticeable drop in elevation (approximately $0.25 \mathrm{~m}$ ) was visible, marking the limits of where soil 2 fill had been spread by a bulldozer. Vegetation in soil 3, including large Baccharus shrubs and high annual grass (Avena barbata), was much more established, indicating that the soil had been left undisturbed for some time. Vegetation on Soils 1 and 2 was dominated by earlier succession species such as yellow star thistle (Centaurea solstitialis), common in highly disturbed areas (Roché and Roché 1991). Elevated Pb levels in soil 3 may also be related to higher clay content (14\%), two to three times higher than the other two soils, as well as to $\mathrm{CEC}\left(22.9 \mathrm{cmol}_{\mathrm{c}} \mathrm{kg}^{-1}\right)$, two to five times higher than the other soils.

The Harbor Bay site, owned by the Port of Oakland, lies at the north end of Oakland International Airport's historic North Field, and immediately south of the Spunkmeyer Soccer Field (see Figure 7b). Built on artificial fill on the tidal flats of Bay Farm Island in 1927, North Field was the airport's first runway (and the longest in the world at the time of its construction, measuring 7,020 feet, or $2.138 \mathrm{~km}$ ). Aerial photographs from 1981 and 1994 show two structures on the western half of the field. In 1994, the eastern half of the site appears to have been graded, and possibly covered with new fill. Elevated $\mathrm{Pb}$ levels appeared at the western end of the Harbor Bay site and seem to be associated with activity visible in the 1994 photo (see Figure 6i). It appears that fill was applied on the eastern half of the site, perhaps diluting $\mathrm{Pb}$ concentrations. Elevated $\mathrm{Pb}$ concentrations are also possibly a legacy of atmospheric deposition from the 
adjacent Engine Test Facility. Cadmium concentrations at this site were five to ten times higher than at the other sites included in the 2009 site-scale analyses; borderline PCB presence ( $>50 \mathrm{mg}$ $\mathrm{kg}^{-1}$ ) was also noted. A 2005 photo also shows a difference in the soils (or possibly vegetation) on the two halves of the site, but both field sampling and the 2009 NAIP photo revealed evidence that new fill had been added on the northern half of the site (Soil 1 in Figure 6i).

As expected, $\mathrm{Pb}$ levels in the three parks sampled were generally low. Since all three sites are now city parks managed by OPR, new soil and turfgrass was likely brought during construction. Several houses built in the 1940s were located on the Columbia Gardens site (Figure 6k), but were demolished in the early 2000s for the widening of $98^{\text {th }}$ Avenue, a major thoroughfare linking Interstate 880 to the airport. A sound-insulating retaining wall now separates the site from $98^{\text {th }}$ Avenue. Lead levels greater than $90 \mathrm{mg} \mathrm{kg}^{-1}$ were clustered at the western end of the site, but do not appear to be related to land use history. According to the 1952 Sanborn map, the Tassaforonga site (Figure 6g) was located on vacant US Government land. At the Brookdale site (Figure 6d), a dwelling and outbuilding were present as late as 1952, but $\mathrm{Pb}$ levels at the site were relatively homogeneous and do not reflect the footprint of the buildings, likely the result of site's development as a park.

Lead levels at two open space areas, King's Estates (Figure 6e) in East Oakland and Jungle Hill (Figure 6c) in Central Oakland, were also low. Both sites are classified as Resource Conservation Areas by OPR, and are maintained infrequently; due to steep slopes, both sites are grazed annually by a herd of goats. Both sites appear unchanged in 1981, 1994, 2005, and 2009 aerial imagery. Lead levels at King's Estates are similar to natural background levels; indeed, the site has never been developed.

At the Jungle Hill site, geomorphology may also have played a part in low $\mathrm{Pb}$ levels. 
Massive mixing of soils following a series of landslides may have diluted whatever surface deposition of $\mathrm{Pb}$ had been there. The site was once home to several houses. No development appears on the 1903 map, which was made 6 years prior to the city's annexation of its eastern territory. By 1925, however, the neighborhood was well established and three houses built on the bluff above the sampling site. During the 1930s, two of the houses collapsed during a landslide. In the 1970s, the final house collapsed. The site became a park in the 1980s, first owned by the Santa Rita Community Land Trust, later ceded to OPR (Oakland Museum of California 1997).

Finally, a high $\mathrm{Pb}$ concentration in one grid-square at the $98^{\text {th }}$ Avenue site (Figure 6h) is possibly a legacy of an old fire station that once stood on the property. A 1952 Sanborn Fire Insurance map shows the Engine No. 26 and Truck No. 8 station on the northeast corner of the lot in approximately the same location as the elevated $\mathrm{Pb}$ levels. The station was still visible in a 1994 aerial photo.

\subsection{Implications for urban agriculture and environmental justice}

This study attempts to answer a fundamental question: is soil $\mathrm{Pb}$ contamination a major obstacle to the scaling up of urban agriculture in Oakland? Based on the data presented here, it appears that the answer is no, with the exception of some areas of West Oakland or former industrial areas along San Leandro Bay. ${ }^{2}$ Overall, total $\mathrm{Pb}$ levels were lower than expected, given

\footnotetext{
${ }^{2}$ The EPA recently launched a two-year Emergency Response project to remediate more than a hundred residential yards in the South Prescott neighborhood of West Oakland. The innovative remediation approach involves amending soils (which average $>800 \mathrm{mg} \mathrm{kg}^{-1}$ ) with fishbone meal, a hydroxyapatite that complexes with soluble $\mathrm{Pb}$ to form the highly recalcitrant pyromorphite (Barringer 2011; Seltenrich 2011).
} 
the city's industrial past and dense freeway network. Lead levels encountered in other cities (e.g., Baltimore, New Orleans, and Boston) may be higher due to longer histories of urban development and $\mathrm{Pb}$ deposition from industry, traffic, and old housing stock. Lead levels reported in those cities are generally much higher than those found in Oakland. In Rust Belt cities, where urban agriculture is spreading rapidly across a post-industrial landscape of vacant lots, the risk of soil $\mathrm{Pb}$ levels at potential urban agriculture sites may also be greater than in Oakland. Finally, it is also possible that low $\mathrm{Pb}$ levels are a result of sampling depth $(0-10 \mathrm{~cm})$. While we followed standard sampling protocol for geochemical mapping under the assumption that soil would be homogenized to a depth of 10 to $15 \mathrm{~cm}$ during agricultural tillage, surface deposition of $\mathrm{Pb}$ would have been diluted.

Given the low $\mathrm{Pb}$ levels, one might argue that such an assessment was a waste of time or resources. On the contrary, assessing these sites for $\mathrm{Pb}$, was not an errant mission but a necessary and precautionary first step in an ongoing effort to expand urban agriculture on Oakland's vacant land. Indeed, $\mathrm{Pb}$ levels are high at many sites. Our analysis captured some broad spatial trends as well as some site-specific trends. This study further documents the uneven distribution of pollutants across the urban landscape, disproportionately impacting low-income populations of color. West Oakland, with its long industrial, age and condition of its housing stock, and long legacy of pollution and vibrant environmental justice movement that arose in response (Costa et al 2002; Walker 2007), bears the brunt of this burden. This study reveals that the highest concentrations lie in the Lower Bottoms and South Prescott neighborhoods, in particular. While these larger-scale trends indicate an uneven distribution of soil $\mathrm{Pb}$ pollution in Oakland, soil sample data and land use histories from individual sites should be closely scrutinized before urban agriculture is practiced at a particular site. As the neighborhood-scale 
data reveal, the range of soil $\mathrm{Pb}$ concentrations at a given site can be incredibly wide and levels at sites dangerously high. Furthermore, assessment of other heavy metals (notably As, $\mathrm{Cd}, \mathrm{Ni}$, and $\mathrm{Zn}$ ) should factor alongside $\mathrm{Pb}$ during the planning process. Broad-based screening for organic contaminants such as PCBs and PAHs can be very expensive, and should therefore be done on a site-specific basis, based on knowledge of previous industrial contamination at or near the site. ${ }^{3}$

\section{Conclusions}

In addition to characterizing $\mathrm{Pb}$ contamination at potential food production sites throughout the city, this research also helps to identify key trends that may be of use to urban agriculture advocates as they consider where to initiate new projects. First, geography matters; soil $\mathrm{Pb}$ concentrations in our study were highest in West Oakland (the oldest part of the city) and lowest in the Oakland hills. Second, land use has a significant effect on $\mathrm{Pb}$ levels. Soil $\mathrm{Pb}$ tended to be higher in gardens and vacant lots, and lower in parks and late-succession open space. Furthermore, analysis of spatial clustering at city- and neighborhood scales combined with land use histories at the site-scale were able to highlight the relationship between certain land use histories and soil $\mathrm{Pb}$ levels that were validated at the site-scale. Third, the city's zoning classifications (which are tied to land use at a coarser level) also affect soil $\mathrm{Pb}$ concentrations. In this study, soil $\mathrm{Pb}$ tended to be higher in residential and industrial zones than in open space. Finally, this research underscores the importance of scale when assessing contamination. While

\footnotetext{
${ }^{3}$ A preliminary assessment of a sub-sample of 11 sites using Dexsil Clor-N-Soil PCB screening kits revealed no significant PCB presence. Nevertheless, further assessment of these sites and others would be prudent.
} 
mapping contamination at city-scale or neighborhood scale can ultimately reveal geographic trends, assessing risks associated with $\mathrm{Pb}$ contamination must ultimately be carried out at individual sites, given the significant variability of soil $\mathrm{Pb}$ concentrations at the site-level. As stakeholders move forward with the promotion of urban agriculture on vacant lots, such a precautionary multi-scalar assessment can shed light not only on potential contamination risks at a particular site, but can also elucidate the uneven and inequitable distribution of contaminant burdens across a socioecological landscape. 


\section{Acknowledgements}

This research was funded by a pilot research grant from the University of California Division of Agriculture \& Natural Resources Analytical Laboratory and a National Science Foundation Doctoral Dissertation Improvement Grant (\#1003598). The project was also made possible by fellowships from the Robert and Patricia Switzer Foundation, Community Forestry and Environmental Research Partnerships, and the Roselyn Lindheim Award in Environmental Design and Public Health. The author thanks Nathan Sayre and Garrison Sposito for their advisory support at various stages during the project, Kevin Koy and Maggi Kelly at UC Berkeley's Geospatial Innovation Facility for GIS troubleshooting and advice, Andy Yang and rest of the Sposito Lab and Barbara Rotz at the Oxford Tract Greenhouse and for the use of their facilities, and Christy Getz for facilitating the pilot grant. Noah Bartlett, Jabari Brown, Eric George, and Stephanie Lin provided invaluable assistance in the field and lab, and Katie Beaton, Joe Boone, Liz Carlisle, Lucy Clark, and Nikki Witt assisted with sampling. Finally, tremendous gratitude also goes to the staff of City Slicker Farms and to members of the community advisory committee members for their inspiration and recommendations. 


\section{References}

Aichner, B., Glaser, B., Zech, W. (2007). Polycyclic aromatic hydrocarbons and polychlorinated biphenyls in urban soils from Kathmandu, Nepal. Organic Geochemistry 38, 700-715.

Alkon, A.H., Agyeman, J. (Eds.) (2011). Cultivating Food Justice: Race, Class, and Sustainability. MIT Press, Cambridge.

Alloway, B.J. (2004). Contamination of soils in domestic gardens and allotments: a brief overview. Land Contamination \& Reclamation 12(3), 179-187.

Bagwell, B. (1982). Oakland: The Story of a City. Oakland Heritage Alliance, Oakland.

Barringer, F. (2011). To nullify lead, add a bunch of fish bones'. New York Times, A12.

Beidleman, L., Kozloff, E. (2003). Plants of the San Francisco Bay Region: Mendocino to Monterey. University of California Press, Berkeley.

Beyers, M., Brown, J., Cho, S., Desautels, A., Gaska, K., Horsley, K., Iton, T., Lee, T., Maker, L., Martin, J., Murgal, N., Schaff, K., Witt, S., Anderson, S.M. (2008). Life and Death from Unnatural Causes: Health and Social Inequity in Alameda County. Alameda County Public Health Department, Oakland.

Blackwood, L.G. (1992). The lognormal distribution, environmental data, and radiological monitoring. Environmental Monitoring and Assessment 21, 193-210.

Brown, R.W., Gonzales, C., Hooper, M.J., Bayat, A.C., Fornerette, A.M., McBride, T.J., Longoria, T., Mielke, H.W. (2008). Soil lead (Pb) in residential transects through Lubbock, Texas: a preliminary assessment. Environmental Geochemistry and Health 30, $541-547$.

Ceccato, V., Dolmen, L. (2011). Crime in rural Sweden. Applied Geography 31 (1), 119-135. 
City of Oakland (n.d.) Survey of Background Metal Concentration Studies, Oakland Urban Land Redevelopment Program.

Clark, H.F., Brabander, D.J., Erdil, R.M. (2006). Sources, Sinks, and Exposure Pathways to Lead in Urban Garden Soil. Journal of Environmental Quality 35, 2066-2074.

Corrigan, M. P. (2011). Growing what you eat: Developing community gardens in Baltimore, Maryland. Applied Geography 31 (4), 1232-1241.

Costa, S., Palaniappan, M., Wong, A.K., Hays, J., Landeiro, C., Rongerude, J. (2002). Neighborhood Knowledge for Change: The West Oakland Environmental Indicators Project. Pacific Institute for Studies in Development, Environment, and Security, Oakland.

Douay, F., Helene, R., Fourrier, H., Heyman, C., Chateau, G. (2007). Investigation of metal concentrations on urban soils, dust and vegetables nearby a former smelter site in Mortagne du Nord, Northern France. Journal of Soils and Sediments 7(3), 143-146.

Eckert, J., Shetty, S. (2011). Food systems, planning and quantifying access: Using GIS to plan for food retail. Applied Geography 31(4), 1216-1223.

Eisenhauer, E. (2001). In poor health: Supermarket redlining and urban nutrition. GeoJournal 53(2), 125-133.

Finster, M.E., Gray, K.A., Binns, H.J. (2004). Lead levels of edibles grown in contaminated residential soils: a field survey. Science of the Total Environment 320, 245-257.

Fisher, J.B., Kelly, M., Romm, J. (2006). Scales of environmental injustice: Combining GIS and spatial analysis for air toxics in West Oakland, California. Health and Place 12, 701-714. 
Gatrell, J. D., Reid, N., Ross, P. (2011). Local food systems, deserts, and maps: The spatial dynamics and policy implications of food geography. Applied Geography 31(4), 11951196.

Getis, A., Ord, J.K. (1992). The Analysis of Spatial Association by Use of Distance Statistics. Geographical Analysis 24(3), 189-206.

Goldenberg, S. (2009). Lead found in Michelle Obama's White House vegetable garden. Guardian, http://www.guardian.co.uk/world/2009/jul/02/michelle-obama-vegetablegarden-lead.

Goldhaber, M.B., Morrison, J.M., Holloway, J.M., Wanty, R.B., Helsel, D.R., Smith, D.B. (2009). A regional soil and sediment geochemical study in northern California. Applied Geochemistry 24(8), 1482-1499.

Gottlieb, R., Joshi, A. (2010). Food Justice. MIT Press, Cambridge.

Gratani, L., Taglioni, S., Crescente, M.F. (1992). The accumulation of lead in agricultural soil and vegetation along a highway. Chemosphere 24(7), 941-949.

Groth, P. (2004). Workers'-cottage and minimal-bungalow districts in Oakland and Berkeley, California, 1870-1945. Urban Morphology 8(1), 13-25.

Hallett, L. F., McDermott, D. (2011). Quantifying the extent and cost of food deserts in Lawrence, Kansas, USA. Applied Geography 31(4), 1210-1215.

Herrera, H., Khanna, N., Davis, L. (2009). Food systems and public health: The community perspective. Journal of Hunger and Environmental Nutrition 4, 430-445.

HOPE Collaborative (2009). A Place with No Sidewalks: An Assessment of Food Access, the Built Environment and Local, Sustainable Economic Development in Ecological MicroZones in the City of Oakland, California in 2008. HOPE Collaborative, Oakland. 
Hornberger, M.I., Luoma, S.N., van Geen, A., Fuller, C., Anima, R. (1999). HIstorical trends of metals in the sediments of San Francisco Bay, California. Marine Chemistry 64, 39-55. Jacobs, D.E., Clickner, R.P., Zhou, J.Y., Viet, S.M., Marker, D.A., Rogers, J.W., Zeldin, D.C., Broene, P., Friedman, W. (2002). The prevalence of lead-based paint hazards in U.S. housing. Environmental Health Perspectives 110(10), A599-A605.

Krauss, M., Wilcke, W. (2003). Polychlorinated napthalenes in urban soils: analysis, concentrations, and relation to other persistent organic pollutants. Environmental Pollution $122,75-89$.

Kremer, P., \&DeLiberty, T. L. (2011). Local food practices and growing potential: Mapping the case of Philadelphia. Applied Geography 31(4), 1252-1261.

Laidlaw, M.A.S., Fillippelli, G.M. (2008). Resuspension of urban soils as a persistent source of lead poisoning in children: A review and new directions. Applied Geochemistry 23(8), 2021-2039.

Leslie, T. F., Frankenfeld, C. L., Makara, M. A. (2012). The spatial food environment of the DC metropolitan area: Clustering, co-location, and categorical differentiation. Applied Geography 35(1-2), 300-307.

Letzing, J. (2004). Oakland's holdout from the iron age: Metal works reinvents itself to survive in a high-tech, white-collar Bay Area. San Francisco Chronicle, http://articles.sfgate.com/2004-03-14/business/17417310_1_foundries-castings-phoenixiron-works.

Limpert, E., Stahel, W.A., Abbt, M. (2001). Log-normal Distributions across the Sciences: Keys and Clues. BioScience 51(5), 341-352. 
Liu, S., Xia, X., Yang, L., Shen, M., Liu, R. (2010). Polycyclic aromatic hydrocarbons in urban soils of different land uses in Beijing, China: Distribution, sources and their correlation with the city's urbanization history. Journal of Hazardous Materials 177(1-3), 10851092.

Ma, Z., Zuckerberg, B., Porter, W. F., Zhang, L. (2012). Use of localized descriptive statistics for exploring the spatial pattern changes of bird species richness at multiple scales. Applied Geography 32(2), 185-194.

Maantay, J., Maroko, A. (2009). Mapping urban risk: Flood hazards, race, \& environmental justice in New York. Applied Geography 29(1), 111-124.

Maroko, A. (2012). Using air dispersion modeling and proximity analysis to assess chronic exposure to fine particulate matter and environmental justice in New York City. Applied Geography 34, 533-547.

McClintock, N. (2011a). From Industrial Garden to Food Desert: Demarcated Devalution in the Flatlands of Oakland, California. In: Alkon, A.H. and Agyeman, J. (Eds.) Cultivating Food Justice: Race, Class, and Sustainability. MIT Press, Cambridge, pp. 89-120.

McClintock, N. (2011b). Cultivation, Capital, and Contamination: Urban Agriculture in Oakland, California. Unpublished PhD dissertation. Department of Geography, University of California, Berkeley.

McClintock, N., Cooper, J. (2009). Cultivating the Commons: An Assessment of the Potential for Urban Agriculture on Oakland's Public Land. Oakland, CA: Institute for Food \& Development Policy/City Slicker Farms/HOPE Collaborative. 
McClintock, N., Wooten, H., Brown, A.H. (2012). Toward a food policy "first step" in Oakland, California: A food policy council's efforts to promote urban agriculture zoning. Journal of Agriculture, Food Systems, and Community Development 2(4), 15-42.

Metcalf, S. S., Widener, M. J. (2011). Growing Buffalo's capacity for local food: A systems framework for sustainable agriculture. Applied Geography 31(4), 1242-1251.

Mielke, H.W., Anderson, J.C., Berry, K.J., Mielke, P.W., Chaney, R.L., Leech, M. (1983). Lead concentrations in inner-city soils as a factor in the child lead problem. American Journal of Public Health 73(12), 1366-1369.

Mielke, H.W., Blake, B., Burroughs, S., Hassinger, N. (1984). Urban lead levels in Minneapolis: The case of Hmong children. Environmental Research 34(1), 64-76.

Mielke, H.W., Gonzales, C., Powell, E., Mielke, P.W. (2008). Urban soil-lead (Pb) footprint: retrospective comparison of public and private properties in New Orleans. Environmental Geochemistry and Health 30, 231-242.

Mielke, H.W., Gonzales, C.R., Powell, E., Jartun, M., Mielke, P.W. (2007). Nonlinear association between soil lead and blood lead of children in metropolitan New Orleans, Louisiana: 2000-2005. Science of the Total Environment 388, 43-53.

Mielke, H.W., Reagan, P.L. (1998). Soil Is an Important Pathway of Human Lead Exposure. Environmental Health Perspectives 106(Supplement 1), 217-229.

Morello-Frosch, R., Pastor, M., Sadd, J. (2002) Integrating environmental justice and the precautionary principle in research and policy making: The case of ambient air toxics exposures and health risks among schoolchidren in Los Angeles. Annals of the American Academy of Political and Social Science 584(1), 47-68. 
Morillo, E., Romero, A.S., Madrid, L., Villaverde, J., Maqueda, C. (2008). Characterization and sources of PAHs and potentially toxic metals in urban environments of Sevilla (southern Spain). Water Air Soil Pollution 187(1), 41-51.

Murphy, K. (2009). For urban gardeners, lead is a concern. New York Times, http://www.nytimes.com/2009/05/14/garden/14lead.html.

Nabulo, G., Oryem-Origa, H., Diamond, M. (2006). Assessment of lead, cadmium, and zinc contamination of roadside soils, surface films, and vegetables in Kampala City, Uganda. Environmental Research 101, 42-52.

NOAA (2004). Climatography of the United States No. 20, 1971-2000, Oakland Museum, CA Station. National Oceanic and Atmospheric Administration, Asheville.

NRCS (2012). Geospatial Data Gateway, http://datagateway.nrcs.usda.gov/.

Oakland Museum of California (1997) The History of Jungle Hill. http://museumca.org/ourland/histoyrjh.html.

Oakland Tribune (1967). Estuary fill plea denied. Oakland Tribune, 2 Jun, 13.

OFPC (2010). Transforming Oakland Food System: A Plan for Action, Oakland Food Policy Council / Food First. http://www.oaklandfood.org.

Palaniappan, M., Prakash, S., Bailey, D. (2006). Paying with Our Health: The Real Cost of Freight Transport in California. Pacific Institute, Oakland.

ProQuest (2012) Digital Sanborn Maps 1867-1970, http://sanborn.umi.com.

Rawlins, B.G., Lark, R.M., Webster, R., O’Donnell, K.E. (2006). The use of soil survey data to determine the magnitude and extent of historic metal deposition related to atmospheric smelter emissions across Humberside, UK. Environmental Pollution 143, 416-426. 
Roché, B.F., Roché, C.T. (1991). Identification, introduction, distribution, ecology, and economics of Centaurea species. In: James, L.F., Evans, J.O., Ralphs, M.H. and CHild, R.D. (Eds.) Noxious Range Weeds, Westview Press, San Francisco.

Runk, D. (2011). Urban gardens tainted with lead, arsenic. Associated Press, http://www.huffingtonpost.com/2011/03/23/urban-gardens-chemicals-leadarsenic_n_839485.html.

Sah, R.N., Miller, R.. (1992). Spontaneous reaction for acid dissolution of biological tissues in closed vessels. Analytical Chemistry 64, 230-233.

Sanchez-Camazano, M., Sanchez-Martin, M.J., Lorenzo, L.F. (1994). Lead and cadmium in soils and vegetables from urban gardens of Salamanca (Spain). The Science of the Total Environment 146/147, 163-168.

SAS Institute (2010). JMP 9 Modeling and Multivariate Methods. SAS Institute Inc., Cary.

Scheyer, J.M. (2004). Estimating dietary risk from soils in urban gardens. Land Contamination \& Reclamation 12(3), 197-203.

Schulin, R., Curchod, F., Mondeshka, M., Daskalova, A., Keller, A. (2007). Heavy metal contamination along a soil transect in the vicinity of the iron smelter of Kremikovtzi (Bulgaria). Geoderma 140(1-2), 52-61.

Scott, M. (1959). The San Francisco Bay Area: A Metropolis in Perspective. University of California Press, Berkeley.

Self, R.O. (2003). American Babylon: Race and the Struggle for Postwar Oakland. Princeton University Press, Princeton.

Seltenrich, N. (2011). How safe is your soil?', East Bay Express. http://www.eastbayexpress.com/gyrobase/how-safe-is-your-soil/Content?oid=2947105. 
Shacklette, H.T., Boerngen, J.G. (1984). Element Concentrations in Soils and Other Surficial Materials of the Coterminous United States. USGS Professional Paper No. 1270. United States Geological Survey, Washington.

Shi, G., Chen, Z., Xu, S., Zhang, J., Wang, L., Bi, C., Teng, J. (2008). Potentially toxic metal contamination of urban soils and roadside dust in Shanghai, China. Environmental Pollution 156(2), 251-260.

Sloan, D. (2006). Geology of the San Francisco Bay Region. California Natural History Guides, University of California Press, Berkeley.

Sutton, P.M., Athanasoulis, M., Flessel, P., Guirguis, G., Haan, M., Schlag, R., Goldman, L.R. (1995). Lead Levels in the Household Environment of Children in 3 High-Risk Communities in California. Environmental Research 68(1), 45-57.

Teichman, J., Coltrin, D., Prouty, K., Bir, W.A. (1993). A survey of lead contamination in soil along Interstate 880, Alameda County, California. American Industrial Hygience Association Journal 54(9), 557-559.

Treuhaft, S., Hamm, M.J., Litjens, C. (2009). Healthy Food For All: Building Equitable and Sustainable Food Systems in Detroit and Oakland. PolicyLink, Oakland.

U.S. Census Bureau (2010). United States Decennial Census. http://factfinder2.census.gov/

UCDANR (2012). How to Manage Pests: The UC Guide to Healthy Lawns. UC IPM Online, http://www.ipm.ucdavis.edu/TOOLS/TURF/TURFSPECIES/index.html.

Walker, R. (2001). Industry builds the city: the suburbanization of manufacturing in the San Francisco Bay Area, 1850-1940. Journal of Historical Geography 27(1), 36-57.

Walker, R. (2007). The Country in the City: The Greening of the San Francsico Bay Area. University of Washington Press, Seattle. 
Wang, F., Guo, D., McLafferty, S. (2012). Constructing geographic areas for cancer data analysis: A case study on late-stage breast cancer risk in Illinois. Applied Geography $35(1-2), 1-11$.

Wang, X.-S., Qin, Y. (2007). Some characteristics of the distribution of heavy metals in urban topsoil of Xuzhou, China. Environmental Geochemistry and Health 29(1), 11-19.

Welch, L.E. (1981). Soil Survey of Alameda County, Western Part. United States Department of Agriculture Soil Conservation Service / University of California Agricultural Experiment Station, Berkeley.

Witzling, L., Wander, M., Phillips, E. (2011). Testing and Educating on Urban Soil Lead: A Case of Chicago Community Gardens. Journal of Agriculture, Food Systems, and Community Development 1(2), 167-185.

Wolf, A., Beegle, D. (1995). Recommended Soil Testing Procedures for the Northeastern United States. Northeast Coordinating Committee on Soil Testing (NEC-67). Northeast Regional Publication No. 493, University of Delaware Agricultural Experiment Station, Newark.

Wu, J., Edwards, R., He, X., Liu, Z., Kleinman, M. (2010). Spatial analysis of bioavailable soil lead concentrations in Los Angeles, California. Environmental Research 110(4), 309317.

Zhang, C., Qiao, Q., Piper, J.D.A., Huan, B. (2011). Assessment of heavy metal pollution from a Fe-smelting plant in urban river sediments using environmental magnetic and geochemical methods. Environmental Pollution 159(10), 3057-3070.

Zhang, P., Wong, D. W., So, B. K. L., Lin, H. (2012). An exploratory spatial analysis of western medical services in Republican Beijing. Applied Geography 32(2), 556-565. 
Table Captions

Table 1: Typology of land use types, level of anthropogenic disturbance, and related edaphic characteristics

Table 2: Mean soil $\mathrm{Pb}$ levels ( $\mathrm{mg} \mathrm{kg}^{-1}$ ) by geographic zone and land use type at 112 sites in Oakland

Table 3: Chemical characteristics of soil samples collected from residential yards in West Oakland ( $\mathrm{n}=260$; data source: City Slicker Farms Backyard Garden Program)

Table 4: Total $\mathrm{Pb}\left(\mathrm{mg} \mathrm{kg}^{-1}\right)$ at selected sites throughout Oakland 


\section{Figure Captions}

Figure 1: Soil sampling locations, Oakland, California

Figure 2: Examples of four land use types used as an analytical typology: gardens (top-left); parks (top-right); vacant land (bottom-left); and open space (bottom-right).

Figu re 3: Total $\mathrm{Pb}$ levels $\left(\mathrm{mg} \mathrm{kg}^{-1}\right)$ by (a) geographic zone, (b) land use type, and (c) zoning classification type of the site and/or surrounding area. Box plots represent $25^{\text {th }}, 50^{\text {th }}$, and $75^{\text {th }}$ percentiles. Red lines indicate the arithmetic mean and one standard error above and below the mean. The dotted line represents the grand mean.

Figure 4: Estimated total soil $\mathrm{Pb}$ concentrations $\left(\mathrm{mg} \mathrm{kg}^{-1}\right)$ in residential yards in West Oakland ( $\mathrm{n}=116$, data source: City Slicker Farms Backyard Garden Program)

Figure 5: A Getis-Ord G* statistical "hot spot" analysis of estimated total $\mathrm{Pb}$ concentrations in West Oakland (left) and Oakland (right). The G ${ }^{*}$ score is also the standard deviation (SD) from the average value of a point's neighbors. A high z-score (red) indicates clustering of high soil $\mathrm{Pb}$ concentrations while a low z-score (green) indicates spatial clustering of low $\mathrm{Pb}$ concentrations. Median z-scores (yellow) indicate that there is no significant spatial relationship between a site's $\mathrm{Pb}$ concentration and that of neighboring points.

Figure 6: Total soil $\mathrm{Pb}$ concentrations $\left(\mathrm{mg} \mathrm{kg}^{-1}\right)$ at eleven sites in Oakland. Each circle represents both the mean $\mathrm{Pb}$ value and mean center of nine soil cores $(0-10 \mathrm{~cm})$ taken from $\mathrm{a}$ 
grid square of $25^{\prime} \times 25^{\prime}$ (a, b, c, d, g, h, k), 50' $\times 50^{\prime}$ (e, f, i), or 100' $\times 100^{\prime}$ (j). Red circles indicate $\mathrm{Pb}$ values above EPA screening level $\left(400 \mathrm{mg} \mathrm{kg}^{-1}\right)$, orange above previous (150 mg $\mathrm{kg}^{-1}$ ) and current $\left(\mathrm{mg} \mathrm{kg}^{-1}\right)$ CHHSL Pb screening levels. Mean centers of each grid square are also represented with black dots in the inset. Sites locations are indicated on the map of Oakland (bottom right).

Figure 7: Historical land use change in East Oakland. The 1918 map (top-left) shows the tidal flats surrounding San Leandro Bay in East Oakland. Approximate locations of the (a) Oakport and (b) Harbor Bay sites are outlined in red. Both sites received significant amounts of artificial fill during the $20^{\text {th }}$ century, much of it likely dredge material from the Alameda Estuary. The East Creek Slough was filled in during the late 1960s. The Harbor Bay site (b) was repeatedly modified as evidenced in photos from 1981 (left), 1994 (center), and 2009 (right). The Engine Test Facility is visible to the right in the 1994 and 2009 images. Sources: Alameda County Chamber of Commerce (1918); City of Oakland Office of Planning (1981, 1994); National Agriculture Imagery Program, USDA (2009). 


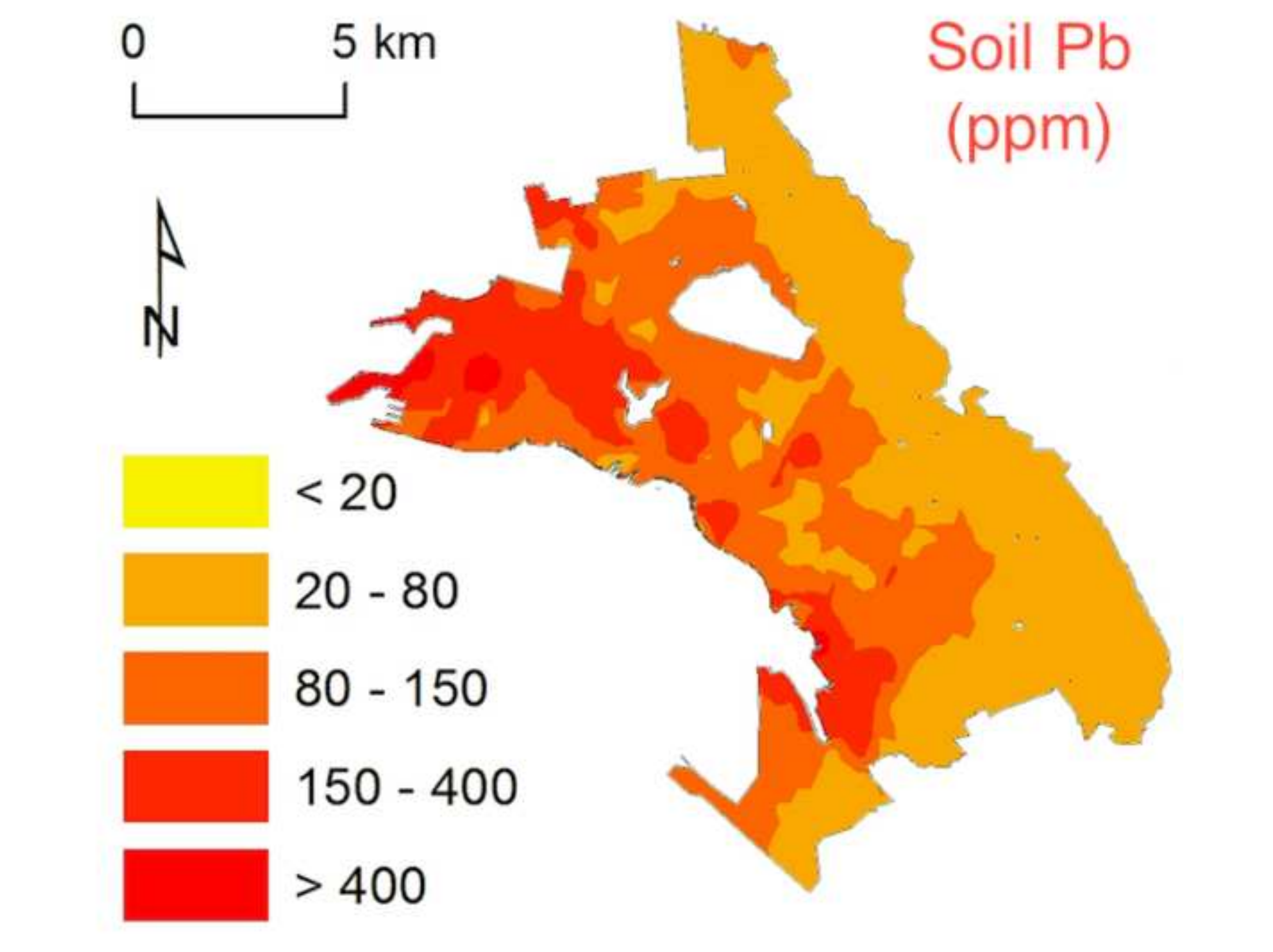

\begin{abstract}
.
\end{abstract}

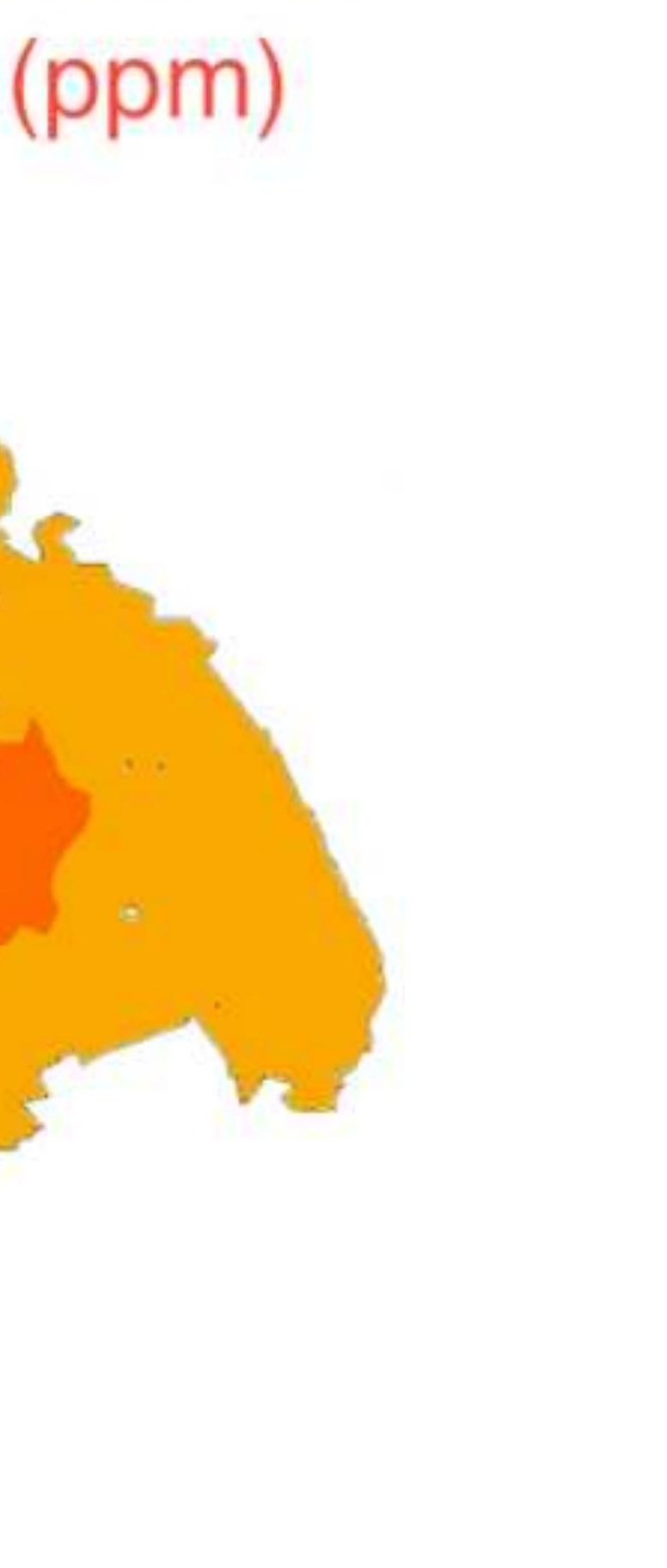

.

Graphical Abstract (for review)
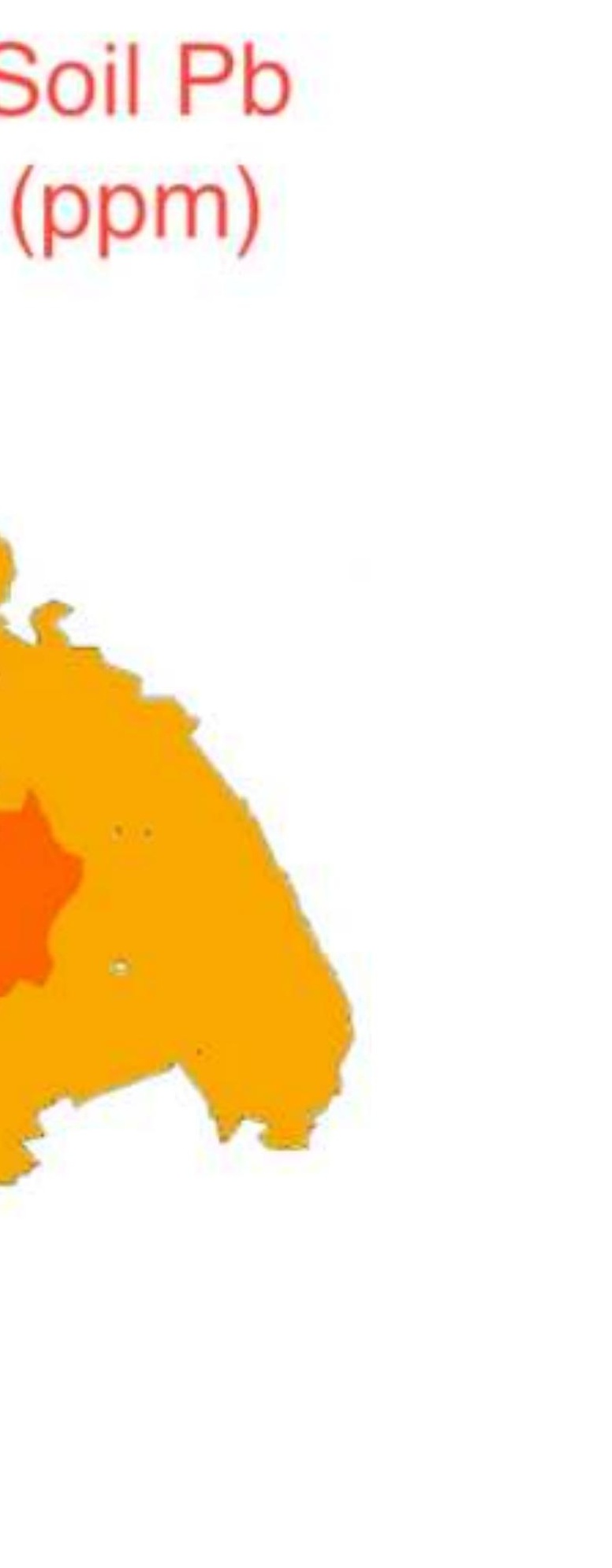

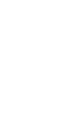

.
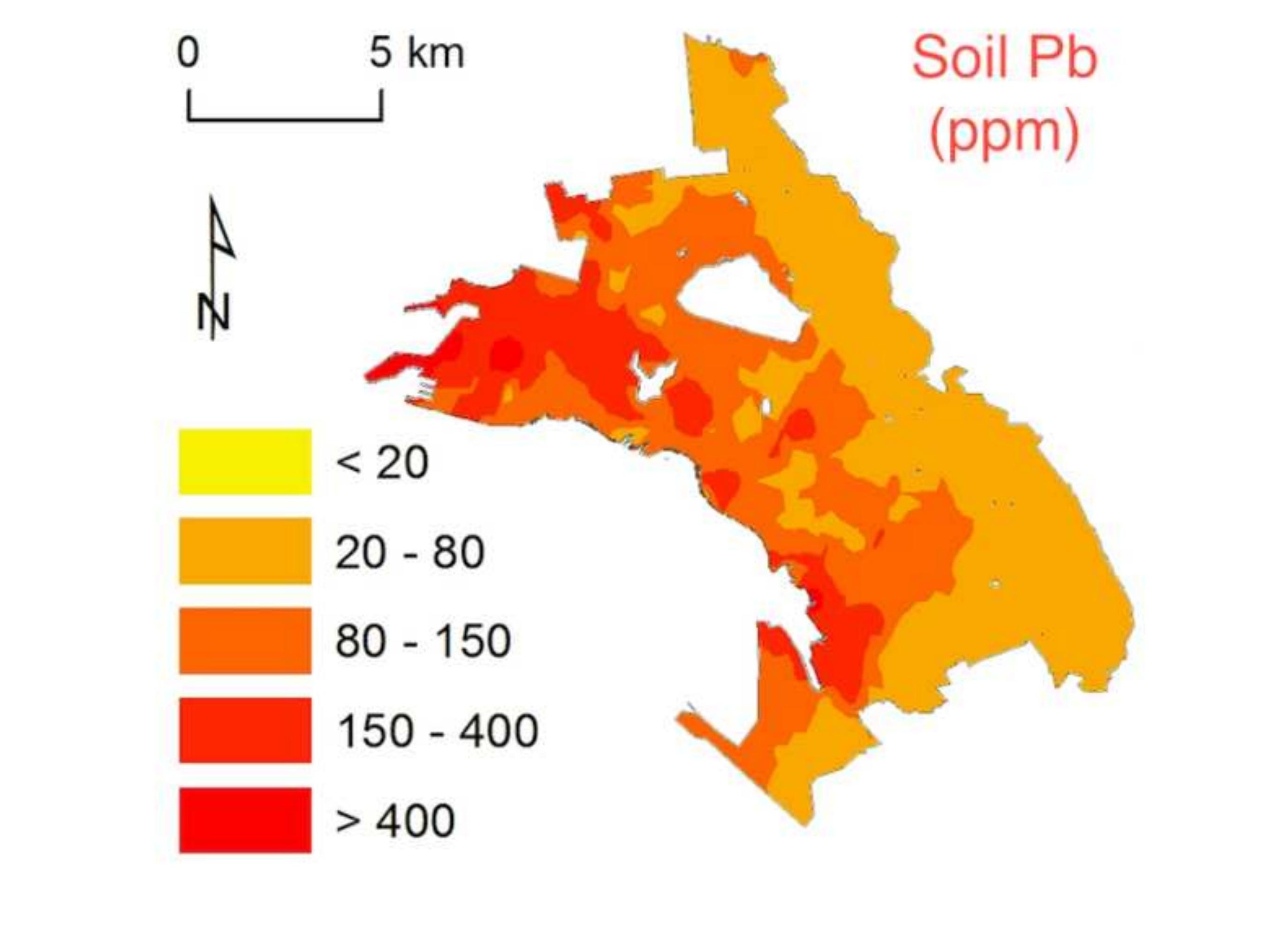


\section{Highlights:}

- Soil lead concentrations in Oakland are closely related to land use and geography.

- Lead contamination is disproportionately higher in low-income community of color.

- Multi-scalar assessment is necessary to capture both site-scale variability and cityscale patterns. 
Click here to download high resolution image

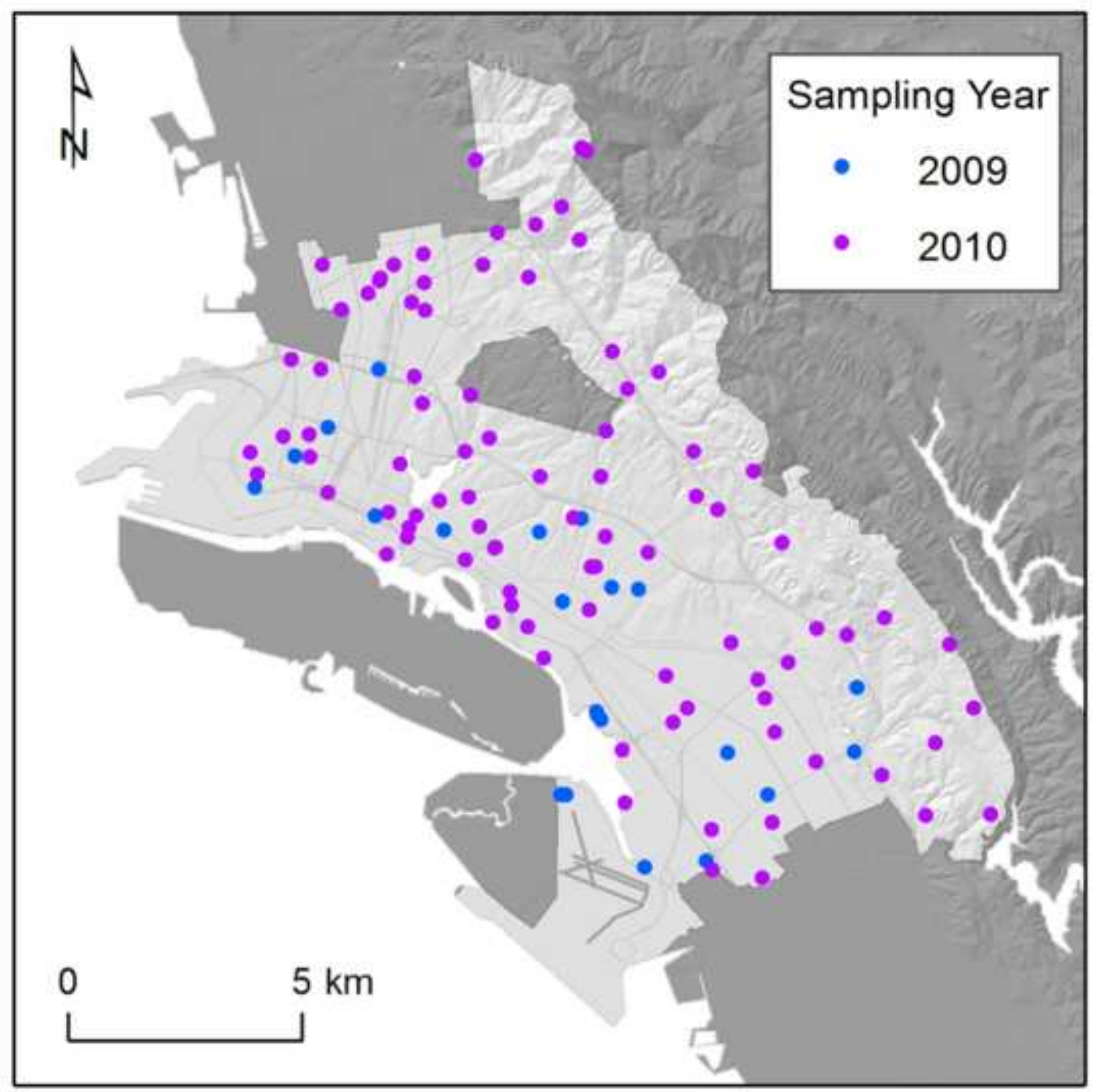


Click here to download high resolution image

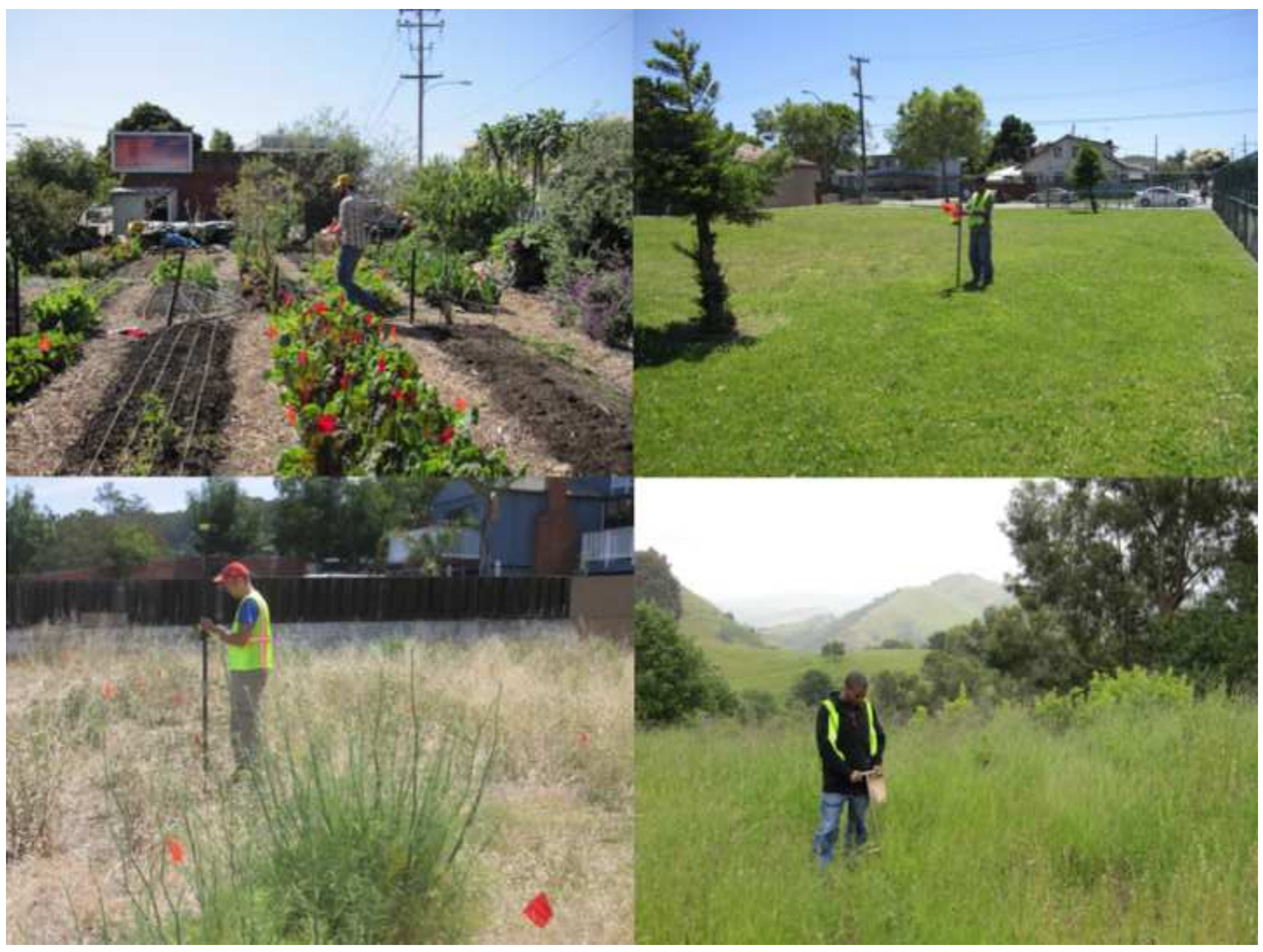



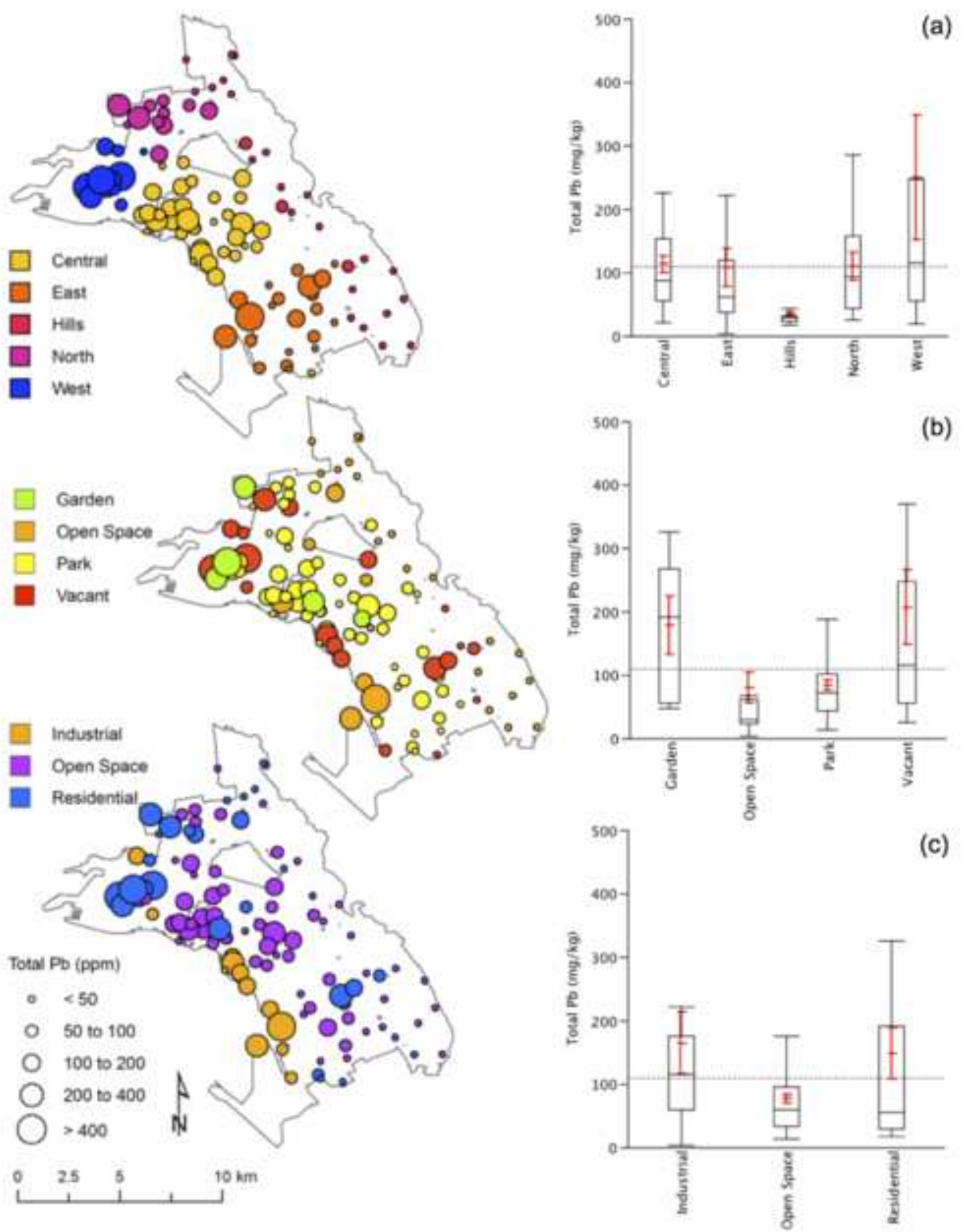


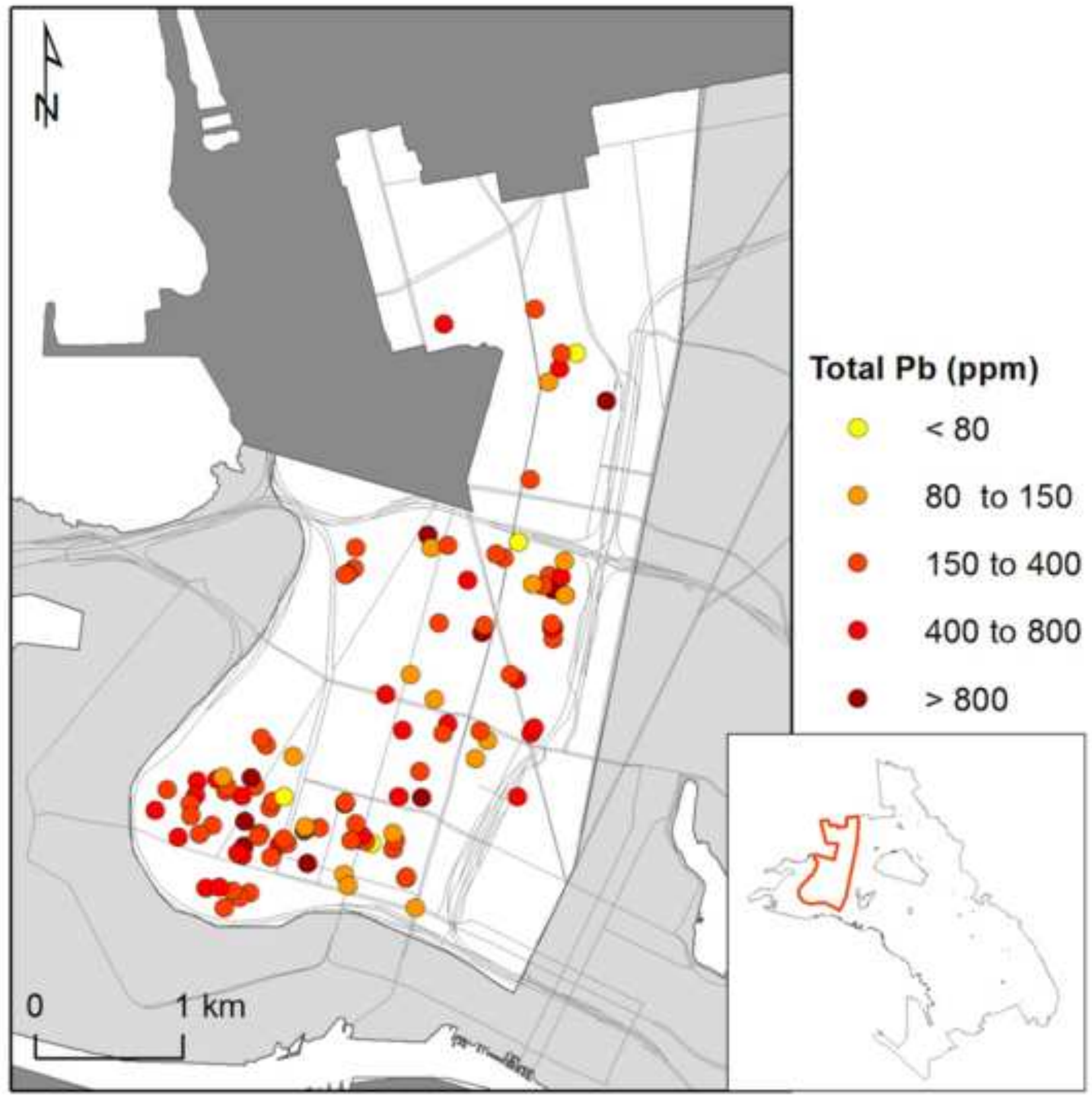



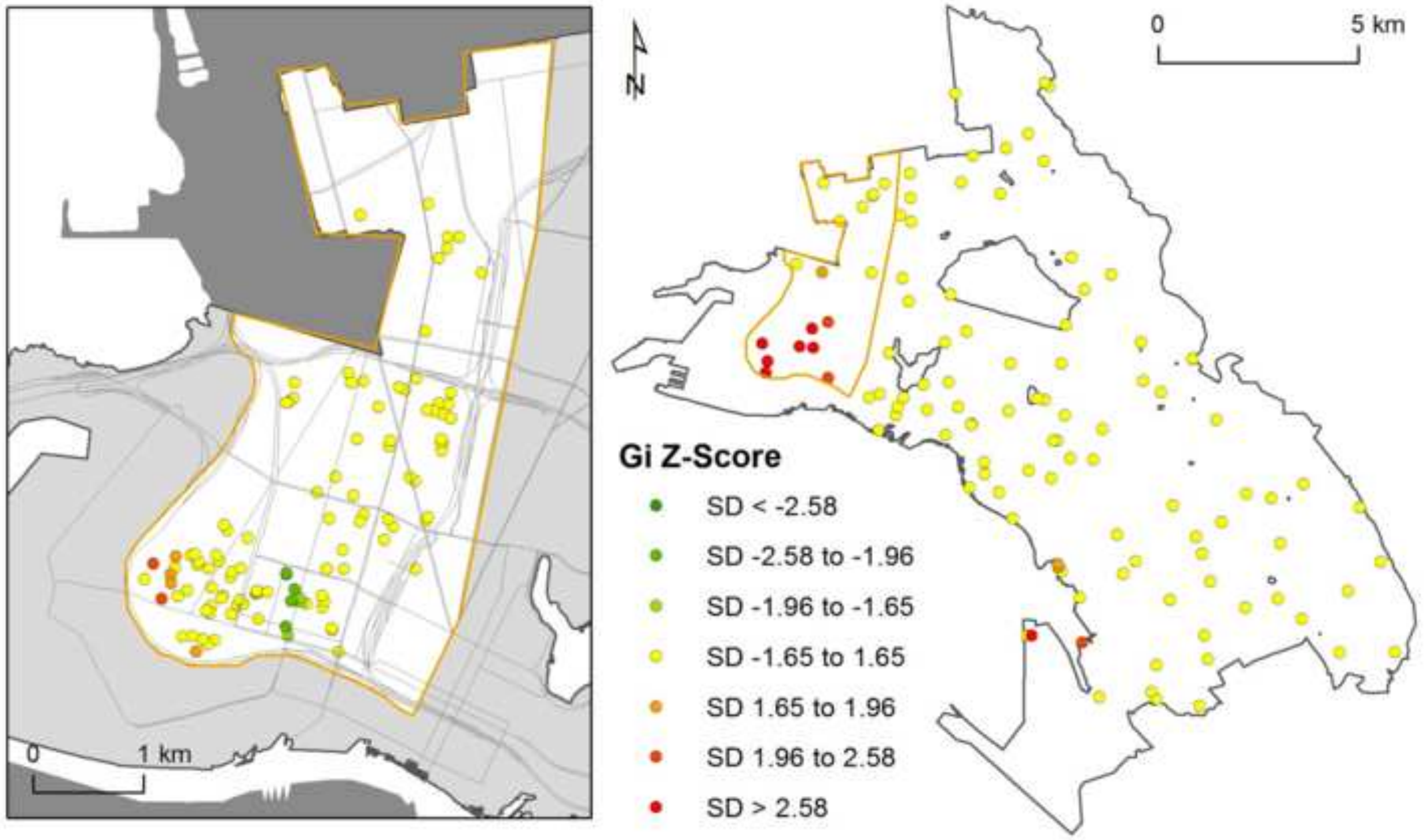
Figure 6 a
Click here to download high resolution image
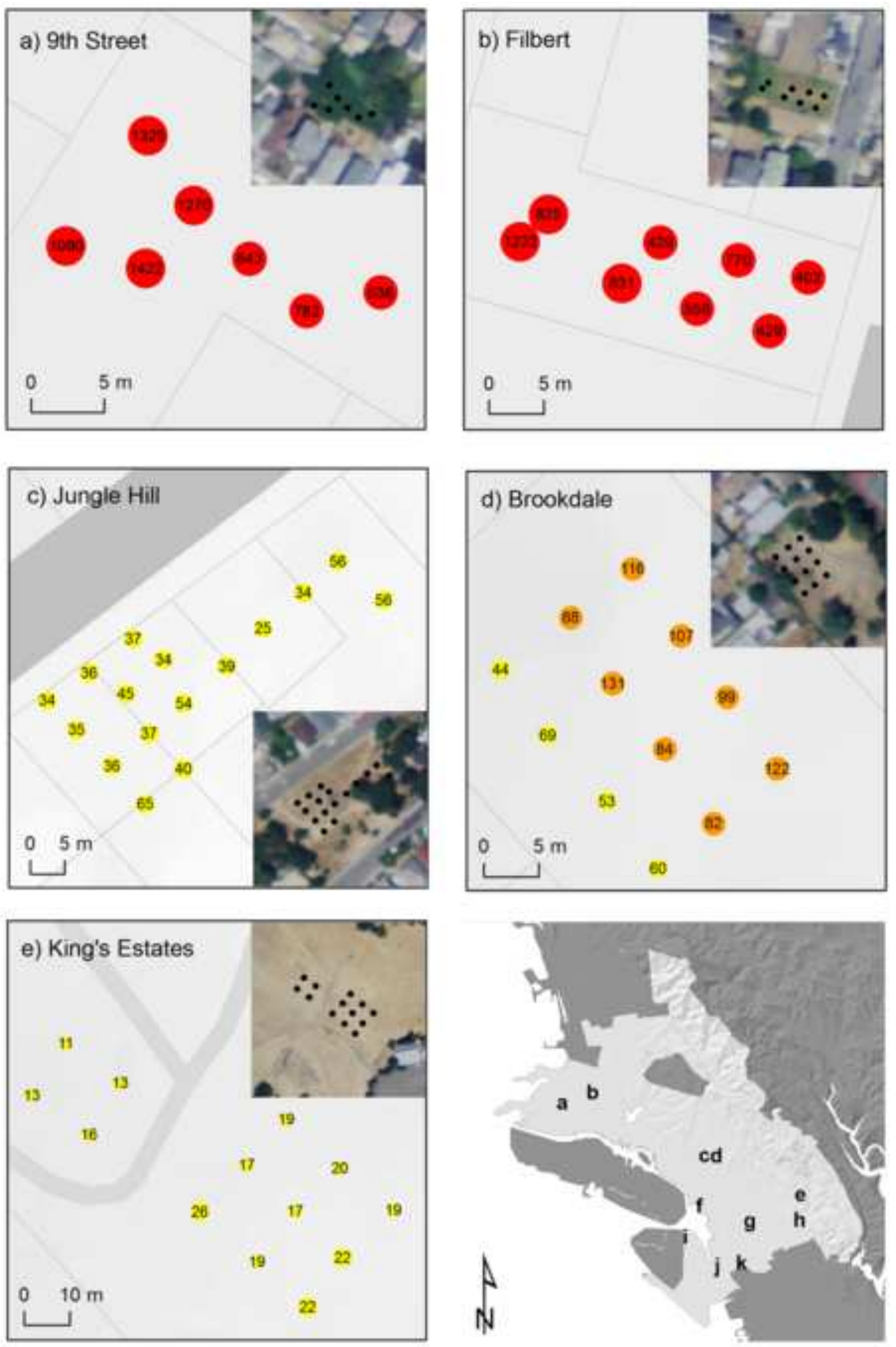

Total Pb

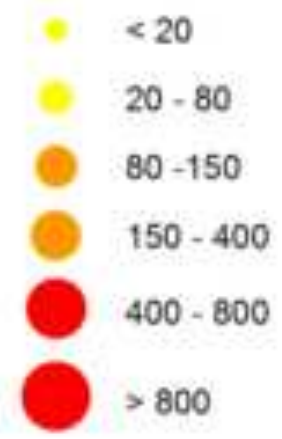


Figure $6 \mathrm{f}$ to $\mathrm{k}$

Click here to download high resolution image
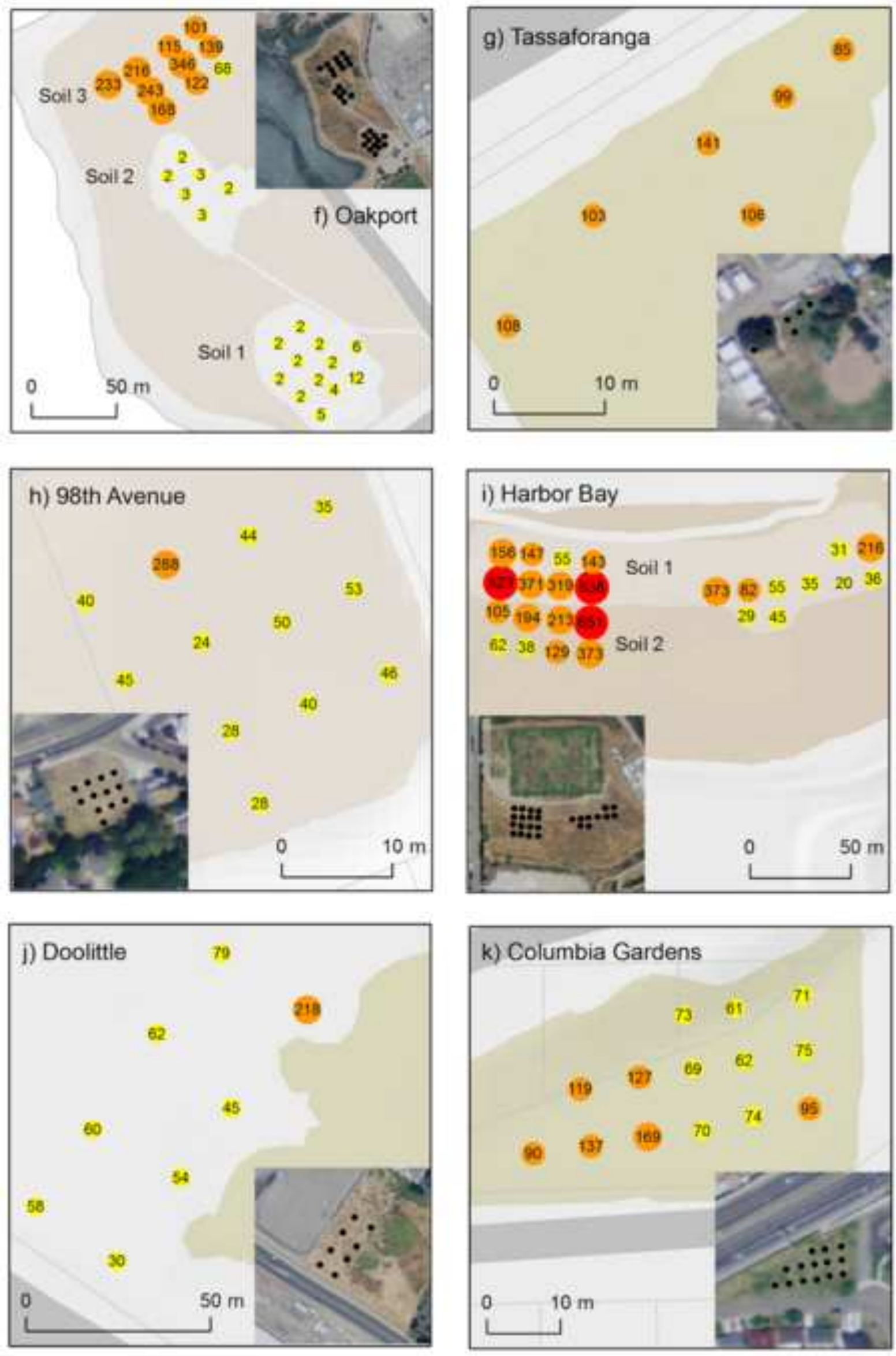

N

Total Pb

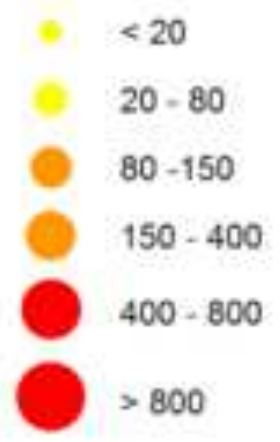


Click here to download high resolution image

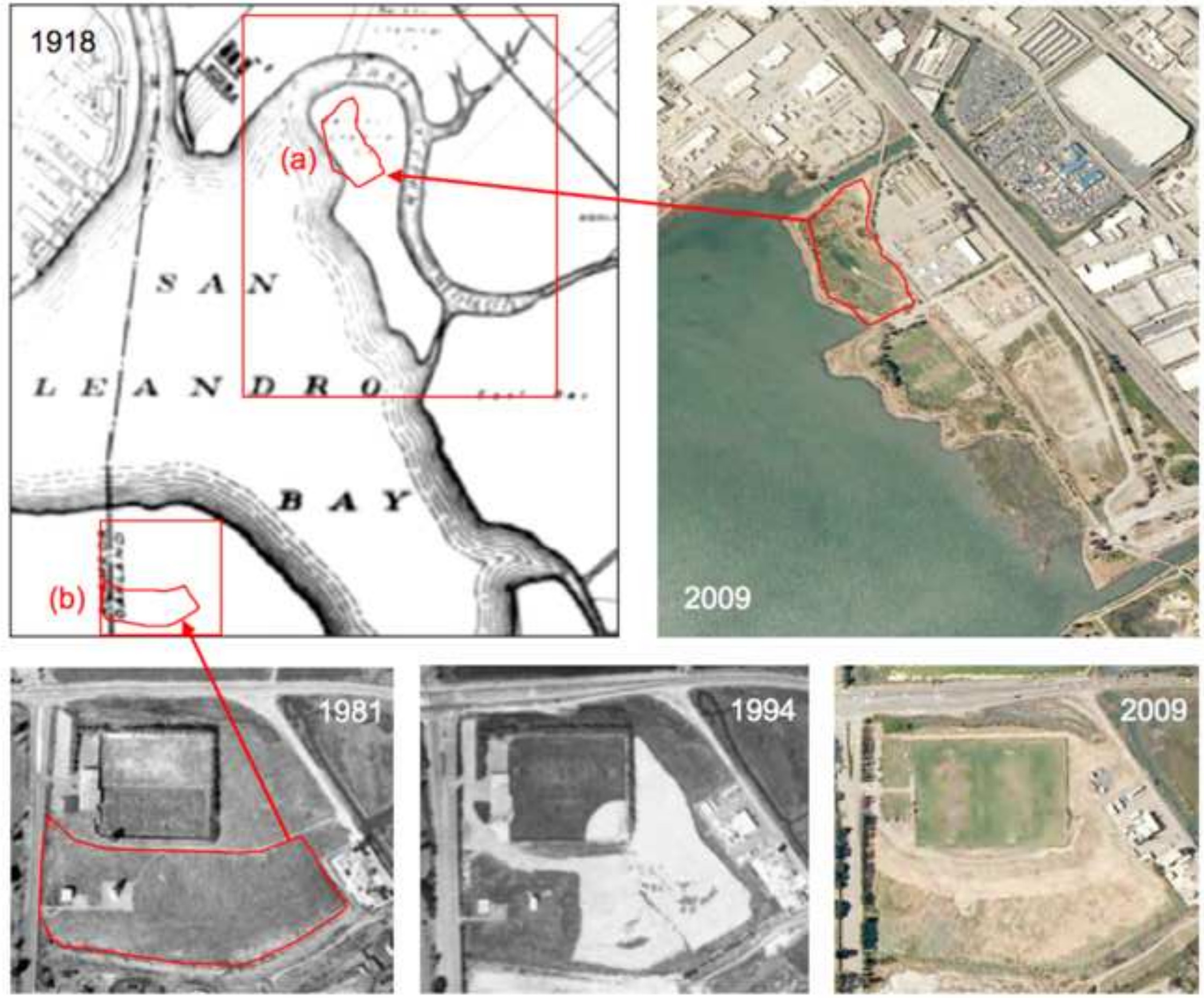


Table 1: Typology of land use types, level of anthropogenic disturbance, and related edaphic characteristics

\begin{tabular}{|l|l|l|l|}
\hline $\begin{array}{l}\text { Land } \\
\text { use }\end{array}$ & $\begin{array}{l}\text { Level of } \\
\text { anthro- } \\
\text { pogenic } \\
\text { disturbance }\end{array}$ & Vegetation & Soils \\
\hline Garden & +++ & $\begin{array}{l}\text { Vegetable crops, e.g., chard/beets (Beta vulgaris), } \\
\text { peas (Pisum sativum), collards/kale (Brassica } \\
\text { oleracea), tomatoes (Solanum lycopersicum), } \\
\text { lettuce (Lactuca sativa) }\end{array}$ & $\begin{array}{l}\text { Frequent, tillage, addition of } \\
\text { compost, cultivation }\end{array}$ \\
\hline Park & +++ & $\begin{array}{l}\text { Turf grasses, e.g., Bermuda grass (Cynodon spp.), } \\
\text { Kentucky bluegrass (Poa pratensis), perennial } \\
\text { ryegrass (Lolium perenne), fescue (Festuca spp.); } \\
\text { frequently irrigated and mowed, occasionally } \\
\text { fertilized }\end{array}$ & $\begin{array}{l}\text { Shallow and compact, high in clay } \\
\text { content; often laid on top of clay } \\
\text { cap or landscape fabric; heavy foot } \\
\text { traffic and occasional vehicle } \\
\text { traffic (mowers, trucks) }\end{array}$ \\
\hline Vacant & ++ & $\begin{array}{l}\text { Early succession invasive species common in } \\
\text { highly disturbed and compacted areas, e.g., } \\
\text { yellow star thistle (Centaurea so/stitialis), fennel } \\
\text { (Foeniculum vulgare), wild radish (Raphanus } \\
\text { sativus), curly dock (Rumex crispus), slim oat } \\
\text { (Avena barbata); some sites mowed annually }\end{array}$ & $\begin{array}{l}\text { Compacted, coarse and gravelly } \\
\text { soil associated with previous } \\
\text { disturbance; occasional traffic, } \\
\text { grading, addition of fill, and/or } \\
\text { other surface disturbance }\end{array}$ \\
\hline $\begin{array}{l}\text { Open } \\
\text { space }\end{array}$ & + & $\begin{array}{l}\text { Native and exotic grasses and weeds, older } \\
\text { succession than vacant; some sites annually } \\
\text { mowed or grazed with goats, but natural cycling } \\
\text { of litter generally occurs }\end{array}$ & $\begin{array}{l}\text { Deeper, more porous soils, some } \\
\text { native; higher in OM due to litter } \\
\text { cycling }\end{array}$ \\
\hline
\end{tabular}


Table 2: Mean soil Pb levels $\left(\mathrm{mg} \mathrm{kg}^{-1}\right)$ by geographic zone and land use type at 112 sites in Oakland

\begin{tabular}{|c|c|c|c|c|c|c|c|}
\hline \multirow{2}{*}{ Type } & \multirow{2}{*}{ Zone } & \multirow{2}{*}{$\mathrm{n}$} & \multicolumn{5}{|c|}{ - } \\
\hline & & & Mean & \pm S.E. & Median & Min & Max \\
\hline \multirow[t]{3}{*}{ Garden } & Central & 3 & 178 & \pm 78.5 & 148 & 59 & 326 \\
\hline & North & 2 & 142 & \pm 95.0 & 142 & 47 & 237 \\
\hline & West & 1 & 248 & $\mathrm{n} / \mathrm{a}$ & 248 & 248 & 248 \\
\hline \multirow[t]{4}{*}{ Open Space } & Central & 6 & 84 & \pm 28.4 & 60 & 41 & 225 \\
\hline & East & 6 & 223 & \pm 113.3 & 176 & 3 & 756 \\
\hline & Hills & 18 & 28 & \pm 1.7 & 28 & 18 & 45 \\
\hline & North & 2 & 111 & \pm 80.0 & 111 & 31 & 191 \\
\hline \multirow[t]{5}{*}{ Park } & Central & 25 & 102 & \pm 13.5 & 87 & 22 & 315 \\
\hline & East & 14 & 60 & \pm 7.3 & 60 & 13 & 107 \\
\hline & Hills & 3 & 54 & \pm 11.9 & 59 & 31 & 71 \\
\hline & North & 8 & 76 & \pm 14.7 & 80 & 25 & 148 \\
\hline & West & 5 & 93 & \pm 30.8 & 77 & 20 & 187 \\
\hline \multirow[t]{5}{*}{ Vacant } & Central & 5 & 167 & \pm 56.2 & 154 & 30 & 370 \\
\hline & East & 4 & 120 & \pm 46.7 & 95 & 43 & 248 \\
\hline & Hills & 3 & 50 & \pm 19.3 & 35 & 26 & 88 \\
\hline & North & 2 & 214 & \pm 71.3 & 214 & 143 & 286 \\
\hline & West & 5 & 407 & \pm 200.6 & 117 & 56 & 979 \\
\hline Total & & 112 & 109 & \pm 13.7 & 64 & 3 & 979 \\
\hline
\end{tabular}


Table 3: Chemical characteristics of soil samples collected from residential yards in West Oakland ( $\mathrm{n}=260$; data source: City Slicker Farms Backyard Garden Program)

\begin{tabular}{|c|c|c|c|c|c|c|c|c|c|}
\hline & \multirow{2}{*}{$\begin{array}{l}\text { Estimated } \\
\text { Total Pb }\end{array}$} & \multirow[b]{2}{*}{$\mathrm{Pb}$} & - & \multicolumn{4}{|c|}{ Modified Morgan-extracted -------------- } & \multirow[b]{2}{*}{$\mathrm{pH}$} & \multirow[b]{2}{*}{$\begin{array}{l}\text { CEC } \\
\left(\text { meq cmol }{ }^{-1}\right)\end{array}$} \\
\hline & & & $\mathrm{Cd}$ & $\begin{array}{l}\mathrm{Ni} \\
\left.--\mathrm{mg} \mathrm{kg}^{-1}\right)\end{array}$ & $\mathrm{Cr}$ & $\mathrm{P}$ & $\mathrm{Ca}$ & & \\
\hline Mean & 369.8 & 35.1 & 0.3 & 0.4 & 0.1 & 58.2 & $3,204.1$ & 6.8 & 17.8 \\
\hline Median & 273.0 & 20.0 & 0.2 & 0.3 & 0.0 & 38.0 & $2,526.5$ & 6.9 & 14.9 \\
\hline Min & 0.1 & 0.0 & 0.0 & 0.0 & 0.0 & 2.0 & 690.0 & 0.5 & 5.6 \\
\hline $\operatorname{Max}$ & $3,329.0$ & 543.0 & 3.3 & 2.3 & 7.4 & $2,074.0$ & $14,620.0$ & 10.1 & 64.3 \\
\hline Std Err & 23.5 & 3.6 & 0.0 & 0.0 & 0.0 & 8.6 & 128.9 & 0.0 & 0.7 \\
\hline $\mathrm{CV}$ & 102.5 & 163.8 & 113.8 & 79.1 & 653.9 & 237.4 & 64.6 & 10.3 & 59.8 \\
\hline
\end{tabular}


Table 4: Total $\mathrm{Pb}\left(\mathrm{mg} \mathrm{kg}^{-1}\right)$ at selected sites throughout Oakland

\begin{tabular}{|c|c|c|c|c|c|c|c|c|}
\hline \multirow{2}{*}{ Site } & \multirow{2}{*}{ Land use } & \multirow{2}{*}{$\begin{array}{l}\text { Grid } \\
\text { samples }^{a} \\
\text { (n) }\end{array}$} & \multirow{2}{*}{$\begin{array}{l}\text { Grid square } \\
\text { size } \\
\text { (m) }\end{array}$} & \multicolumn{5}{|c|}{---- Total Pb $\left(\mathrm{mg} \mathrm{kg}^{-1}\right)$------- } \\
\hline & & & & \multicolumn{2}{|c|}{ Mean ( \pm S.E.) } & Median & Min & Max \\
\hline \multicolumn{9}{|l|}{ West Oakland } \\
\hline 9th St. & Vacant & 7 & $7.52 \times 7.52$ & 1,023 & \pm 126.0 & 1,080 & 636 & 1,422 \\
\hline $\begin{array}{l}\text { Filbert } \\
\text { Central Oakland }\end{array}$ & Vacant & 8 & $7.52 \times 7.52$ & 685 & \pm 101.4 & 664 & 402 & 1,233 \\
\hline Brookdale & Park & 12 & $7.52 \times 7.52$ & 88 & \pm 8.1 & 86 & 44 & 131 \\
\hline $\begin{array}{l}\text { Jungle Hill } \\
\text { East Oakland }\end{array}$ & Open Space & 16 & $7.52 \times 7.52$ & 41 & \pm 2.7 & 37 & 25 & 65 \\
\hline Columbia Gardens & Park & 14 & $7.52 \times 7.52$ & 92 & \pm 8.8 & 75 & 61 & 169 \\
\hline Doolittle & Vacant & 8 & $30.48 \times 30.48$ & 74 & \pm 21.2 & 56 & 30 & 218 \\
\hline Harbor Bay (soil 1) & Open Space & 18 & $15.24 \times 15.24$ & 176 & \pm 40.9 & 113 & 20 & 536 \\
\hline Harbor Bay (soil 2) & Open Space & 8 & $15.24 \times 15.24$ & 221 & \pm 71.9 & 162 & 38 & 651 \\
\hline Oakport (soil 1) & Open Space & 12 & $15.24 \times 15.24$ & 4 & \pm 0.9 & 2 & 2 & 12 \\
\hline Oakport (soil 2) & Open Space & 6 & $15.24 \times 15.24$ & 3 & \pm 0.2 & 3 & 2 & 3 \\
\hline Oakport (soil 3) & Open Space & 10 & $15.24 \times 15.24$ & 175 & \pm 26.6 & 154 & 68 & 346 \\
\hline $\begin{array}{l}\text { Tassaforonga } \\
\text { Oakland Hills }\end{array}$ & Park & 6 & $7.52 \times 7.52$ & 107 & \pm 7.6 & 105 & 85 & 141 \\
\hline $98^{\text {th }}$ Ave. & Vacant & 12 & $7.52 \times 7.52$ & 60 & \pm 20.9 & 42 & 24 & 288 \\
\hline King's Estates & Open Space & 13 & $15.24 \times 15.24$ & 18 & \pm 1.2 & 19 & 11 & 26 \\
\hline
\end{tabular}

${ }^{a}$ each grid sample was composited from 9 soil cores 